INTR

32,7

56

Received 21 April 2020

Revised 1 October 2020

15 February 2021

24 May 2021

Accepted 24 May 2021

\section{Antecedents and consequences of the perceived usefulness of smoking cessation online health communities}

\author{
Chenglong $\mathrm{Li}$ \\ Department of Management and Entrepreneurship, Turku School of Economics, \\ University of Turku, Turku, Finland \\ Hongxiu Li \\ Department of Information and Knowledge Management, Tampere University, \\ Tampere, Finland, and \\ Reima Suomi \\ Department of Management and Entrepreneurship, Turku School of Economics, \\ University of Turku, Turku, Finland
}

\begin{abstract}
Purpose - An empirical study investigated the antecedents to perceived usefulness (PU) and its consequences in the context of smoking cessation online health communities (OHCs).

Design/methodology/approach - To validate a research model for perceived informational support, perceived emotional support and perceived esteem support, the authors conducted a partial-least-squares analysis of empirical data from an online survey $(N=173)$ of users of two smoking cessation OHCs. The proposed model articulates these as antecedents to PU from a social support perspective, and knowledge sharing and continuance intention are expressed as consequences of PU.

Findings - The empirical study identified that the PU of smoking cessation OHCs is influenced by perceived emotional support and perceived esteem support, and perceived informational support indirectly affects PU via these factors. In turn, PU exerts a positive influence on both knowledge sharing and continuance intention. Also, knowledge sharing positively affects continuance intention.

Originality/value - The study contributes to scholarship on users' postadoption behavior in the context of smoking cessation $\mathrm{OHCs}$ by disentangling the antecedents to PU from a social support perspective and pinpointing some important consequences of PU. The research also has practical implications for managing smoking cessation $\mathrm{OHCs}$.
\end{abstract}

Keywords Online health communities, Perceived usefulness, Social support, Knowledge sharing, Continuance intention

Paper type Research paper

\footnotetext{
(C) Chenglong Li, Hongxiu Li and Reima Suomi. Published by Emerald Publishing Limited. This article is published under the Creative Commons Attribution (CC BY 4.0) licence. Anyone may reproduce, distribute, translate and create derivative works of this article (for both commercial and non-commercial purposes), subject to full attribution to the original publication and authors. The full terms of this licence may be seen at http://creativecommons.org/licences/by/4.0/legalcode

The authors are grateful to the editor and the anonymous referees for their insightful comments. This manuscript is a revised and expanded version of a paper entitled "Antecedents and Consequences of Perceived Usefulness of Smoking Cessation Online Health Communities" published at the 53rd Hawaii International Conference on System Sciences (HICSS), 2020. This work is supported by the grant from the Finnish Foundation for Economic Education (Liikesivistysrahasto) (No. 16-9095).
} 


\section{Introduction}

Internet-based smoking cessation interventions that allow social interactions among smokers have ballooned in popularity in recent years. It is estimated that more than 12 million adult smokers in the USA sought related assistance via the Internet in 2017 alone (Graham and Amato, 2019). Recently, smoking cessation online health communities (OHCs) have received considerable attention from academics and practitioners too. Smoking cessation OHCs can be defined as social networks in which individuals can interact with each other with regard to kicking the smoking habit, seeking or offering related social support (Chen et al., 2019; Mpinganjira, 2018). Smoking cessation OHCs provide several benefits to smokers. Firstly, they offer smokers a communication channel through which they can interact with thousands of current smokers or ex-smokers without facing space and time restrictions. Also importantly, these $\mathrm{OHCs}$ allow users to remain anonymous by hiding their identity when online. This can help smokers maintain their privacy and avoid smoking-related stigma (e.g. blame, shame or negative stereotypes). Prior research suggests that participation in smoking cessation OHCs may lead at least to positive outcomes such as abstinence in the short term (Graham et al., 2015).

Quitting smoking is more like a marathon than a sprint. Even though some smokers may not have smoked for a while, they still need constant assessment and repeated interventions to prevent relapse. A longitudinal study spanning 25 years found that about $39 \%$ of former smokers - those who had quit smoking successfully - reported relapsing at least once during the smoking cessation process (Caraballo et al., 2014). For those who have quit in the recent past, the use of smoking cessation OHCs can help sustain the abstinence and aid in becoming permanently free of smoking (Cheung et al., 2015, 2020). In addition, they may also support other users through sharing tips and experiences of the smoking cessation journey (Dickerson et al., 2016; White et al., 2020). Obviously, smoking cessation OHCs can benefit both current and former smokers. Though the potential benefits for users are clear, a challenge remains: low participation levels (Saul et al., 2016). There are unanswered questions about how smokers can be motivated to keep using the $\mathrm{OHC}$ as their smoking cessation process unfolds and about how to inspire them to contribute knowledge to the OHCs. Information systems (IS) scholars have posited that users' continuance intention toward an IS is critical for its success and sustainability (Bhattacherjee, 2001). In addition, knowledge sharing has been identified as important for the long-term success and sustainability of online communities (Chiu et al., 2006). Therefore, it is essential to investigate the factors influencing users' intention to continue using smoking cessation $\mathrm{OHCs}$ and their knowledge-sharing behavior in these communities.

Although research has paid a large amount of attention to either knowledge sharing in OHCs (e.g. Yan et al., 2016; Zhang et al., 2020; Zhang et al., 2017) or behavior related to their continuance intention (e.g. Song et al., 2018; Wu, 2018), little research has investigated the links between these distinct postadoption behaviors. Given the importance of both - users' continuance intention toward smoking cessation $\mathrm{OHCs}$ and knowledge sharing in these $\mathrm{OHCs}$ - for the sustainability of smoking cessation $\mathrm{OHCs}$, investigation of the link between the two should fruitfully advance understanding of the interdependence of these postadoption behaviors in smoking cessation OHCs.

Researchers have argued that perceived usefulness (PU) is a crucial motivator for continuance intention toward an IS (e.g. Bhattacherjee, 2001; Davis, 1989; Venkatesh and Davis, 2000) and an important driver of knowledge sharing in online communities (e.g. Hashim and Tan, 2018; Yuan et al., 2016). While their studies have provided important insights into the role of $\mathrm{PU}$ in postadoption behaviors, prior research has ignored the specific context of smoking cessation OHCs and the needs of users of these OHCs. Unlike diseases that rely predominantly on physical treatment, many issues or problems relevant to smoking cessation could be alleviated via behavioral interventions, such as counseling and social support. By affording such interventions, smoking cessation OHCs can be an important and effective part of improving abstinence (Graham et al., 2016), yet prior research has produced
Perceived usefulness of smoking cessation $\mathrm{OHC}$ 
INTR 32,7 no evidence of whether PU retains its dominant role in determining users' postadoption behaviors in the particular context of smoking cessation $\mathrm{OHCs}$.

Moreover, understanding of the external determinants of the PU of smoking cessation $\mathrm{OHCs}$ remains fragmented. Some research has found PU to be influenced by external factors (Davis, 1989). For instance, Zhang et al. (2012) discovered that the PU of computer-based communication media was affected by perceived communication efficiency and support for the information process. According to Agarwal (2000), PU is determined by how users feel connected to the value gained from using an IS. Smokers turn to smoking cessation OHCs not only to request informational support related to kicking the habit but also to seek emotional and esteem support for reducing smoking cessation-related stresses (Huang et al., 2019; Zhang and Yang, 2015). Informational support, emotional support and esteem support have been highlighted as important resources and/or of great value in these OHCs (Wang et al., 2017; Zhang and Yang, 2015). However, few studies have examined what determines PU of smoking cessation OHCs from a social support perspective. Hence, there is clear value in investigating whether the three types of social support that users experience from a smoking cessation $\mathrm{OHC}$ can predict the $\mathrm{PU}$ of that $\mathrm{OHC}$.

Furthermore, in the trans-theoretical model (Prochaska and Velicer, 1997), smokers move through six stages of quitting smoking: precontemplation, contemplation, preparation, action, maintenance and termination. Smokers at different stages of smoking cessation differ in their needs (Velicer et al., 2006) and tend to provide social support in distinct patterns (Zhang and Yang, 2015), which might lead to differential perceptions of the social support and the utility of smoking cessation OHCs between users. This might also influence continuance intention and users' knowledge sharing in the OHCs. Hence, a finer-grained investigation of users' stage in quitting smoking as a possible moderator is necessary for a more nuanced understanding of how such factors affect user-perceived utility of smoking cessation OHCs and their postadoption behaviors.

Against this backdrop, our research was designed to investigate the antecedents and consequences of the PU in the context of smoking cessation OHCs specifically. To reach this objective, we anchored our work in social support theory (Cohen, 2004; Cohen and Wills, 1985), proposing that user-perceived informational support, emotional support and esteem support are key antecedents to the PU of smoking cessation OHCs. In light of prior research into PU's impact on postadoption behaviors, we posited that PU of these OHCs leads to the two distinct postadoption behaviors identified earlier: continuance intention and knowledge sharing. Furthermore, we considered age, gender, country and smoking cessation stage as possible moderators of the proposed relationships. The proposed research model was tested with empirical data collected via an online survey with 173 responses, from two smoking cessation $\mathrm{OHCs}$, in two countries: China and Finland.

Our discussion begins with a review of prior literature on both PU and social support theory in Section 2. Afterward, Section 3 presents the proposed research model and our hypotheses, and Section 4 introduces the research method. Then, we discuss the research findings in Section 5, followed by addressing the theoretical contributions and practical implications in Section 6. Finally, the limitations and future directions for research are presented in Section 7.

\section{Theoretical background}

2.1 Perceived usefulness

PU has been defined as "the degree to which a person believes that using a particular system would enhance his or her job performance” (Davis, 1989, p. 320), and nonwork settings are also relevant. This factor has been identified as a key determinant of attitude and intended behavior related to an IS in the postadoption stage. In framings such as the postacceptance 
model of IS continuance, PU has been posited to be a dominant factor in predicting intentions to continue using an IS (Bhattacherjee, 2001). The association between PU and continuance intention has been validated in various contexts, such as e-government (Hamid et al., 2016), e-learning (Alraimi et al., 2015) and general OHCs (Wu, 2018). Also, a link has been found between PU and other postadoption behaviors. For instance, Li and Liu (2014) discovered that it influences the word-of-mouth behavior of e-service users, and the findings of Yuan et al. (2016) suggest that PU has a positive impact on knowledge sharing in online travel communities. A study by Hashim and Tan (2018) identified users' intention to share knowledge in online business communities as driven by the PU of the community.

Another stream of research focuses on investigating antecedents to PU of an IS from various perspectives. For instance, Agarwal and Karahanna (2000) found the PU of the World Wide Web to be influenced by the individual users and situational factors, such as the individual-specific traits of playfulness, personal innovativeness and user experience. In addition, Zhang et al. (2012) suggested that system characteristics affect the PU of computerbased communication systems. In the general OHCs context, $\mathrm{Wu}(2018)$ found that social support, information quality and service quality influence PU of the OHCs. Also, user perceptions of the hedonic and utilitarian aspects of an IS could affect the PU of that IS - for instance, curiosity, information quality and enjoyment affect PU of travel-review websites (Wang and Li, 2019).

Recent research has paid increasing attention to the PU of IS in the specific context of smoking cessation. For instance, Ali et al. (2019) found that PU of mobile health and quickresponse code technologies to be positively associated with smokers' use intention and actual use of both technologies. In research on digital educational games for students' smoking cessation, the PU of such games showed a positive association with the students' intention to quit smoking (Guo et al., 2020). However, all these studies focused on outcomes from PU and ignored the antecedents to it, at least with regard to smoking cessation OHCs. While scholars have investigated PU from multiple angles - among them user characteristics (Agarwal and Karahanna, 2000), features of the technology (Zhang et al., 2012) and hedonic and utilitarian value (Wang and Li, 2019) - and although prior research on smoking cessation OHCs has highlighted the importance of online social support for enhancing users' success in quitting smoking (Cheung et al., 2015; Graham et al., 2016), no empirical evidence has attempted to answer the question of whether social support can predict PU in the context of smoking cessation OHCs. This gap prompted us to examine the role of social support in predicting PU in the specific context of smoking cessation OHCs.

\subsection{Social support theory}

Social support refers to information and actions that lead an individual to believe that he or she is "cared for and loved, esteemed and valued" and "belongs to a network of communication and mutual obligation" (Cobb, 1976, p. 300). Prior literature suggests that social support affects human health and serves as a stress buffer (Cohen, 2004; Cohen and Wills, 1985). Social support has been found to be associated with positive outcomes in various health domains, such as alcohol withdrawal (Peirce et al., 2000) and smoking cessation specifically, smokers are more likely to show improved smoking cessation performance when receiving active social support via strong social ties to partners, family members and close friends (Wagner et al., 2004; Westmaas et al., 2010). Likewise, social support expressed along weaker social ties, such as those in smoking cessation $\mathrm{OHCs}$, has been suggested to lead to positive outcomes. For instance, Graham et al. (2015) stated that smokers who participate in smoking cessation $\mathrm{OHCs}$ might be more likely than nonmembers to stop smoking within three months.

\section{Perceived usefulness of smoking cessation $\mathrm{OHC}$}


INTR 32,7

60

Numerous studies have investigated social support in OHCs. These studies, summarized in Table 1, represent two major streams of research. One stream, examining how social support is exchanged in $\mathrm{OHCs}$, employs various typologies of social support to categorize the support via content analysis, with one frequently used typology being the social support behavior code (SSBC) developed by Cutrona and Suhr (1992). According to the SSBC, there are five types of social support: (1) Informational support involves communicating facts or suggestions. Often, the informational support in $\mathrm{OHC}$ includes messages about diseases, treatments and how one can cope with stress caused by illness. (2) Emotional support communicates love and caring. Such support usually produces a sense of being cared about by other users. In OHCs, sympathy and empathy shown through the communication are common examples of emotional support. (3) Esteem support involves communicating confidence and respect for others' abilities. In OHCs, esteem support often is given when the messages conveyed state or imply that the reader is capable of and competent in dealing with a disease. Such support is generally intended to enhance users' self-confidence. (4) Network support encourages a sense of belonging to a social network of people with similar health concerns. Finally, (5) tangible support is the provision of goods or financial support needed in a stressful environment. In various contexts, such as OHCs related to HIV/AIDS (Coursaris and Liu, 2009), autism spectrum disorders (ASDs) (Mohd Roffeei et al., 2015) and smoking cessation (Zhang and Yang, 2015), informational support and emotional support have been found to be the two main types of social support exchanged, followed by esteem support and network support, while tangible support is quite uncommon. This might be because $\mathrm{OHC}$ users are generally dispersed geographically and stay anonymous online; only rarely do they provide material goods physically or directly supply financial support via the OHC (Huang et al., 2014, 2019).

The other research stream focuses on the role of social support in OHCs. For instance, Wang et al. (2017) investigated which types of social support affect users' participation and found that informational support, seeking emotional support and companionship are three important determinants of users' continued participation in breast-cancer OHCs. The findings of Chen et al. (2019) indicate that the exchange of social support is determined by the structural capital developed in OHCs. Also, they found that social support has a positive influence on users' health literacy and health-attitude valence. The work of Huang et al. (2019), in turn, identified that structural capital, cognitive capital and relational capital all facilitate the provision of emotional support, whereas only cognitive capital promotes the provision of informational support.

The literature shows that social support theory may be amenable to explaining users' perceptions of the usefulness of smoking cessation OHCs from the individual perspective. Firstly, the literature on social support points to a positive correlation between that support and health. This may partly explain the positive impact of social support from $\mathrm{OHCs}$ on the success of one's smoking cessation efforts. Secondly, social support theory is useful in identifying the types of social support in smoking cessation OHCs and examining their roles in smoking cessation OHCs. While these OHCs are collectives of users with a common goal of quitting smoking, users differ in the types of social support they need for coping with the stresses and uncertainties related to reaching that goal. Since social support from smoking cessation OHCs might increase user perceptions of the usefulness of smoking cessation $\mathrm{OHCs}$, thereby further affording abstinence, social support theory represents a suitable theoretical framework for examining the determinants of PU with regard to smoking cessation OHCs. Informed by findings from prior research on several types of social support in OHCs, our study focused on three important types of social support identified in the literature: informational, emotional and esteem support. We excluded tangible support because of its rarity in OHCs (Huang et al., 2019; Wang et al., 2017). Also, we omitted network support from consideration in our study because it has been argued to be distinct from social support and functions differently in OHCs (Huang et al., 2019). Since social support is a 


\begin{tabular}{|c|c|c|c|c|c|c|}
\hline Authors & Context & $\begin{array}{l}\text { Purpose of } \\
\text { research }\end{array}$ & $\begin{array}{l}\text { Types of social } \\
\text { support }\end{array}$ & $\begin{array}{l}\text { Method } \\
\text { (sample size) }\end{array}$ & Research findings & $\begin{array}{l}\text { Perceived } \\
\text { usefulness of }\end{array}$ \\
\hline \multirow[t]{2}{*}{$\begin{array}{l}\text { Coursaris } \\
\text { and Liu } \\
(2009)\end{array}$} & \multirow[t]{2}{*}{ HIV/AIDS } & \multirow[t]{2}{*}{$\begin{array}{l}\text { To identify and } \\
\text { analyze the types } \\
\text { of social support } \\
\text { exchanged in } \\
\text { OHCs }\end{array}$} & \multirow{2}{*}{$\begin{array}{l}\text { Informational } \\
\text { support, emotional } \\
\text { support, } \\
\text { esteem support, } \\
\text { network support } \\
\text { and tangible } \\
\text { support }\end{array}$} & \multirow[t]{2}{*}{$\begin{array}{l}\text { Content } \\
\text { analysis } \\
(5,000 \text { posts })\end{array}$} & \multirow{2}{*}{$\begin{array}{l}\text { Informational } \\
\text { support }(41.6 \%) \\
\text { and emotional } \\
\text { support }(16.0 \%) \\
\text { are shared most } \\
\text { frequently, } \\
\text { followed by } \\
\text { network support } \\
(6.8 \%) \text { and esteem } \\
\text { support }(6.4 \%) \text {, } \\
\text { while tangible } \\
\text { assistance is } \\
\text { uncommon }(0.8 \%)\end{array}$} & cessation OHC \\
\hline & & & & & & \\
\hline $\begin{array}{l}\text { Chuang and } \\
\text { Yang (2012) }\end{array}$ & Alcoholism & $\begin{array}{l}\text { To explore the } \\
\text { types of } \\
\text { supportive } \\
\text { interaction in } \\
\text { online social } \\
\text { networks }\end{array}$ & $\begin{array}{l}\text { Emotional support, } \\
\text { esteem support and } \\
\text { network support }\end{array}$ & $\begin{array}{l}\text { Content } \\
\text { analysis ( } 493 \\
\text { forum } \\
\text { messages, } 423 \\
\text { journal } \\
\text { messages and } \\
\text { 1,180 "notes") }\end{array}$ & $\begin{array}{l}\text { Of all the forms of } \\
\text { nurturing } \\
\text { support, } \\
\text { emotional } \\
\text { support appeared } \\
\text { most frequently, } \\
\text { with network and } \\
\text { esteem support } \\
\text { appearing in } \\
\text { patterns of } \\
\text { varying } \\
\text { combinations }\end{array}$ & \\
\hline $\begin{array}{l}\text { Cavallo } \\
\text { et al. }(2014)\end{array}$ & $\begin{array}{l}\text { Physical } \\
\text { activity }\end{array}$ & $\begin{array}{l}\text { To examine the } \\
\text { relationship } \\
\text { between social } \\
\text { support and } \\
\text { physical activity } \\
\text { among young } \\
\text { women }\end{array}$ & $\begin{array}{l}\text { Companionship, } \\
\text { esteem, and } \\
\text { informational } \\
\text { support }\end{array}$ & $\begin{array}{l}\text { Survey } \\
(N=134)\end{array}$ & $\begin{array}{l}\text { Esteem support } \\
\text { affects physical } \\
\text { activity directly, } \\
\text { whereas } \\
\text { companionship } \\
\text { influences it } \\
\text { indirectly }\end{array}$ & \\
\hline $\begin{array}{l}\text { Guo and } \\
\text { Goh (2014) }\end{array}$ & HIV/AIDS & $\begin{array}{l}\text { To investigate } \\
\text { the types of social } \\
\text { interaction over } \\
\text { time in OHCs }\end{array}$ & $\begin{array}{l}\text { Socioemotional } \\
\text { support (positive } \\
\text { emotions, negative } \\
\text { emotions and } \\
\text { intimacy } \\
\text { relationships) and } \\
\text { informational } \\
\text { (medically related } \\
\text { and not medically } \\
\text { related) support }\end{array}$ & $\begin{array}{l}\text { Content } \\
\text { analysis } \\
(2,243 \\
\text { messages })\end{array}$ & $\begin{array}{l}\text { With time, the } \\
\text { number of } \\
\text { emotional } \\
\text { messages } \\
\text { increases by } \\
\text { almost a third, } \\
\text { coming to surpass } \\
\text { informational } \\
\text { messages as the } \\
\text { dominant content } \\
\text { of all online } \\
\text { postings. } \\
\text { Additionally, } \\
\text { medically related } \\
\text { informational } \\
\text { messages eclipse } \\
\text { non-medical- } \\
\text { condition-related } \\
\text { ones as time } \\
\text { passes } \\
\quad \text { (continued) }\end{array}$ & $\begin{array}{r}\text { Table } 1 . \\
\text { Summary of prior } \\
\text { studies on social } \\
\text { support in OHCs }\end{array}$ \\
\hline
\end{tabular}


INTR 32,7

\section{2}

\begin{tabular}{|c|c|c|c|c|c|}
\hline Authors & Context & $\begin{array}{l}\text { Purpose of } \\
\text { research }\end{array}$ & $\begin{array}{l}\text { Types of social } \\
\text { support }\end{array}$ & $\begin{array}{l}\text { Method } \\
\text { (sample size) }\end{array}$ & Research findings \\
\hline $\begin{array}{l}\text { Huang et al. } \\
\text { (2014) }\end{array}$ & $\begin{array}{l}\text { Breast } \\
\text { cancer and } \\
\text { prostate } \\
\text { cancer }\end{array}$ & $\begin{array}{l}\text { To contrast } \\
\text { community } \\
\text { members' } \\
\text { support behavior } \\
\text { and } \\
\text { companionship } \\
\text { activities in } \\
\text { OHCs }\end{array}$ & $\begin{array}{l}\text { Informational } \\
\text { support, emotional } \\
\text { support, } \\
\text { esteem support, } \\
\text { network support } \\
\text { and support } \\
\text { requests }\end{array}$ & $\begin{array}{l}\text { Mixed } \\
\text { methods } \\
(2,053 \\
\text { messages, } \\
\text { from two } \\
\text { OHCs) }\end{array}$ & $\begin{array}{l}\text { Five types of } \\
\text { social-support } \\
\text { exchange are } \\
\text { displayed in } \\
\text { OHCs: support } \\
\text { requests and } \\
\text { informational, } \\
\text { emotional, esteem } \\
\text { and network } \\
\text { support. Also, five } \\
\text { types of } \\
\text { companionship } \\
\text { activities were } \\
\text { identified: } \\
\text { celebration, chat } \\
\text { or idea sharing, } \\
\text { life events, } \\
\text { updates and } \\
\text { event/ } \\
\text { information- } \\
\text { sharing }\end{array}$ \\
\hline $\begin{array}{l}\text { Yan and } \\
\text { Tan (2014) }\end{array}$ & $\begin{array}{l}\text { Mental } \\
\text { health }\end{array}$ & $\begin{array}{l}\text { To investigate } \\
\text { the effect of } \\
\text { online } \\
\text { interactions on } \\
\text { health conditions }\end{array}$ & $\begin{array}{l}\text { Informational } \\
\text { support, emotional } \\
\text { support and } \\
\text { companionship }\end{array}$ & $\begin{array}{l}\text { Partially } \\
\text { observed } \\
\text { Markov } \\
\text { decision } \\
\text { process model }\end{array}$ & $\begin{array}{l}\text { Informational } \\
\text { support is the } \\
\text { most prevalent } \\
\text { type of support in } \\
\text { OHCs, and } \\
\text { emotional } \\
\text { support is } \\
\text { important for } \\
\text { helping patients } \\
\text { reach a healthier } \\
\text { state }\end{array}$ \\
\hline $\begin{array}{l}\text { Mohd } \\
\text { Roffeei et al. } \\
(2015)\end{array}$ & $\begin{array}{l}\text { Autism } \\
\text { spectrum } \\
\text { disorders } \\
\text { (ASDs) }\end{array}$ & $\begin{array}{l}\text { To examine the } \\
\text { types of social- } \\
\text { support } \\
\text { messages } \\
\text { exchanged in } \\
\text { OHCs related to } \\
\text { ASDs }\end{array}$ & $\begin{array}{l}\text { Informational } \\
\text { support, emotional } \\
\text { support, } \\
\text { network support, } \\
\text { esteem support and } \\
\text { tangible support }\end{array}$ & $\begin{array}{l}\text { Content } \\
\text { analysis } \\
(3,637 \\
\text { messages })\end{array}$ & $\begin{array}{l}\text { Informational } \\
\text { support }(30.7 \%) \text { is } \\
\text { frequently } \\
\text { shared, followed } \\
\text { by emotional } \\
\text { support }(27.8 \%) \text {. } \\
\text { Network- and } \\
\text { esteem-support } \\
\text { messages account } \\
\text { for } 20.97 \% \text { and } \\
20.2 \% \text { of the } \\
\text { content, } \\
\text { respectively. } \\
\text { Tangible support } \\
\text { is rare }(0.4 \%)\end{array}$ \\
\hline
\end{tabular}

Table 1. 


\begin{tabular}{|c|c|c|c|c|c|c|}
\hline Authors & Context & $\begin{array}{l}\text { Purpose of } \\
\text { research }\end{array}$ & $\begin{array}{l}\text { Types of social } \\
\text { support }\end{array}$ & $\begin{array}{l}\text { Method } \\
\text { (sample size) }\end{array}$ & Research findings & $\begin{array}{l}\text { Perceived } \\
\text { usefulness of }\end{array}$ \\
\hline \multirow[t]{2}{*}{$\begin{array}{l}\text { Reifegerste } \\
\text { et al. (2017) }\end{array}$} & \multirow[t]{2}{*}{ Obesity } & \multirow[t]{2}{*}{$\begin{array}{l}\text { To investigate } \\
\text { the effect of } \\
\text { forum activities } \\
\text { on social support }\end{array}$} & \multirow[t]{2}{*}{$\begin{array}{l}\text { Informational } \\
\text { support and } \\
\text { emotional support }\end{array}$} & \multirow[t]{2}{*}{$\begin{array}{l}\text { Survey } \\
(N=230)\end{array}$} & \multirow{3}{*}{$\begin{array}{l}\text { Forum activities } \\
\text { have a positive } \\
\text { effect on } \\
\text { perceived } \\
\text { informational and } \\
\text { emotional } \\
\text { support } \\
\text { Tangible support } \\
\text { and appraisal } \\
\text { support } \\
\text { significantly } \\
\text { influence } \\
\text { perceived risk, } \\
\text { whereas } \\
\text { emotional } \\
\text { support and } \\
\text { esteem support } \\
\text { significantly } \\
\text { influence self- } \\
\text { efficacy related to } \\
\text { health }\end{array}$} & $\begin{array}{r}\text { cessation OHC } \\
\mathbf{6 3}\end{array}$ \\
\hline & & & & & & \\
\hline $\begin{array}{l}\text { Deng and } \\
\text { Liu (2017) }\end{array}$ & $\begin{array}{l}\text { Nonserious } \\
\text { illness (e.g. } \\
\text { fevers, colds } \\
\text { and eye } \\
\text { discomfort) }\end{array}$ & $\begin{array}{l}\text { To examine } \\
\text { social support's } \\
\text { influence on } \\
\text { consumers' } \\
\text { intention to seek } \\
\text { health } \\
\text { information on } \\
\text { mobile social- } \\
\text { media websites }\end{array}$ & $\begin{array}{l}\text { Tangible support, } \\
\text { emotional support, } \\
\text { esteem support, } \\
\text { and appraisal } \\
\text { support }\end{array}$ & $\begin{array}{l}\text { Survey } \\
(N=439)\end{array}$ & & \\
\hline $\begin{array}{l}\text { Flickinger } \\
\text { et al. }(2017)\end{array}$ & HIV/AIDS & $\begin{array}{l}\text { To investigate } \\
\text { the types of social } \\
\text { support in OHCs }\end{array}$ & $\begin{array}{l}\text { Emotional support, } \\
\text { esteem support, } \\
\text { informational } \\
\text { support, and } \\
\text { instrumental } \\
\text { support }\end{array}$ & $\begin{array}{l}\text { Content } \\
\text { analysis ( } 840 \\
\text { posts) }\end{array}$ & $\begin{array}{l}\text { Messages } \\
\text { offering support } \\
\text { focus } \\
\text { predominantly on } \\
\text { emotional } \\
\text { support }(41 \%) \text {, } \\
\text { followed by } \\
\text { network }(27 \%) \text {, } \\
\text { esteem }(24 \%) \text {, } \\
\text { informational } \\
(18 \%) \text {, and } \\
\text { instrumental }(2 \%) \\
\text { support }\end{array}$ & \\
\hline \multirow[t]{2}{*}{$\begin{array}{l}\text { Wang et al. } \\
(2017)\end{array}$} & \multirow[t]{2}{*}{$\begin{array}{l}\text { Breast } \\
\text { cancer }\end{array}$} & \multirow[t]{2}{*}{$\begin{array}{l}\text { To analyze OHC } \\
\text { users' online } \\
\text { interactions and } \\
\text { reveal which } \\
\text { types of social } \\
\text { support affect } \\
\text { their } \\
\text { participation }\end{array}$} & \multirow[t]{2}{*}{$\begin{array}{l}\text { Informational } \\
\text { support, emotional } \\
\text { support, and } \\
\text { companionship }\end{array}$} & \multirow[t]{2}{*}{$\begin{array}{l}\text { Text-mining } \\
\text { (posts from } \\
\text { October } 2002 \\
\text { to August } \\
2013 \text { ) }\end{array}$} & $\begin{array}{l}\text { Providing } \\
\text { informational } \\
\text { support, seeking } \\
\text { emotional } \\
\text { support, and } \\
\text { companionship } \\
\text { are predictors of } \\
\text { continued } \\
\text { participation in } \\
\text { OHCs }\end{array}$ & \\
\hline & & & & & (continued) & Table 1. \\
\hline
\end{tabular}


INTR 32,7

\begin{tabular}{lll}
\hline Authors & Context & $\begin{array}{l}\text { Purpose of } \\
\text { research }\end{array}$ \\
\hline $\begin{array}{l}\text { Song } \text { et al. } \\
\text { (2018) }\end{array}$ & Weight loss & $\begin{array}{l}\text { To identify the } \\
\text { types of social } \\
\text { support } \\
\text { expressed and } \\
\text { investigate their } \\
\text { roles in } \\
\text { sustaining } \\
\text { participation in } \\
\text { OHCs }\end{array}$ \\
&
\end{tabular}

Chen et al. OHCs related (2019)

Huang et al. (2019) to general conditions, mental and behavioral conditions and specific diseases

Three OHCs: for breast, colorectal and prostate cancer
To explore the influence of structural capital on social-support exchange in OHCs and the impacts of sharing social support on health literacy and attitudes

To examine the antecedents to social-support provision and companionship activities in $\mathrm{OHCs}$
Informational support and emotional support

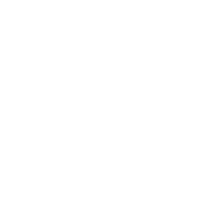

Informational support, emotional support, and companionship

$\begin{aligned} & \text { Types of social } \\ & \text { support }\end{aligned}$
Informational
support, emotional
support, and
companionship

Method (sample size) Research findings

Text-mining Emotional (survival data support and from 2nd August 2008 to 20 th December 2013) companionship experienced within $\mathrm{OHC}$ s have a greater influence on continued participation than does informational support received in them.

Informational support from outside OHCs has a greater effect on users' continued participation than does either $\mathrm{OHC}$ external emotional support or companionship Integrated Structural capital content is an antecedent analysis and to the exchange of socialnetwork analysis (96,360

discussion threads containing 867,799 replies posted by 22,484 participants)

Integrated content analysis and social network analysis (usergenerated data from 387 members) social support in

OHCs. Provision

of social support (i.e., offering informational and emotional support) has a stronger impact than the receipt of social support on health literacy and attitudes Structural, relational, and cognitive capital affect the provision of emotional support. Structural and relational capital influence companionship. Only cognitive capital facilitates the provision of informational support

Table 1. 
mechanism for reducing uncertainty and stress, the analysis could have been unnecessarily complicated by the inclusion of network support, which scholars regard as the shared activities for their own sake rather than for buffering against a stressful situation (Albrecht and Adelman, 1987; Huang et al., 2019; Rook, 1987; Thoits, 1986).

\section{The research model and hypotheses}

\subsection{The proposed model}

Proceeding from the literature on postadoption behaviors (Bhattacherjee, 2001; Venkatesh and Davis, 2000; Yuan et al., 2016), we expected to find PU to be an important factor in predicting both continuance intention and knowledge sharing in smoking cessation OHCs and to find a link between these two postadoption behaviors. Furthermore, research examining social support in OHCs led us to posit that three particular types of perceived social support (perceived informational support, perceived emotional support and perceived esteem support) are central antecedents to the PU of smoking cessation OHCs. In addition, we hypothesized that perceived informational support influences perceived emotional and perceived esteem support in these OHCs. Age, gender, country and smoking cessation stage were tested as possible moderators. Table 2 presents the definitions of the constructs in the proposed research model. Figure 1 summarizes the model itself.

\subsection{Hypotheses}

Emotional support - that is, communicating encouragement, concern, understanding, sympathy and even love to others (Cutrona and Suhr, 1992) - can help individuals restore
Perceived usefulness of smoking cessation $\mathrm{OHC}$

\begin{tabular}{|c|c|}
\hline Construct & Definition \\
\hline Continuance intention (CI) & $\begin{array}{l}\text { Willingness to continue using the smoking cessation OHC (Bhattacherjee, } \\
\text { 2001) }\end{array}$ \\
\hline $\begin{array}{l}\text { Perceived emotional support } \\
\text { (PEMS) }\end{array}$ & $\begin{array}{l}\text { Users' perceptions of the care, empathy, encouragement and even love } \\
\text { received in the smoking cessation OHC (Cutrona and Suhr, 1992) }\end{array}$ \\
\hline $\begin{array}{l}\text { Perceived esteem support } \\
\text { (PESS) }\end{array}$ & $\begin{array}{l}\text { Users' perceptions surrounding respect and confidence gained in their } \\
\text { abilities via the smoking cessation OHC (Cutrona and Suhr, 1992) }\end{array}$ \\
\hline $\begin{array}{l}\text { Perceived informational } \\
\text { support (PIS) }\end{array}$ & $\begin{array}{l}\text { User perceptions connected with the information on smoking cessation } \\
\text { received in the smoking cessation OHC, such as advice, facts and referrals } \\
\text { (Cutrona and Suhr, 1992) }\end{array}$ \\
\hline Knowledge sharing (KS) & $\begin{array}{l}\text { The behavior of exchanging information, experience and skills related to } \\
\text { smoking cessation in the smoking cessation OHC (Hsu et al., 2007) }\end{array}$ \\
\hline Perceived usefulness (PU) & $\begin{array}{l}\text { The degree to which a user believes that using the smoking cessation OHC } \\
\text { will enhance his or her success in ceasing to smoke (Davis, 1989) }\end{array}$ \\
\hline
\end{tabular}

Table 2.

Constructs in the research model

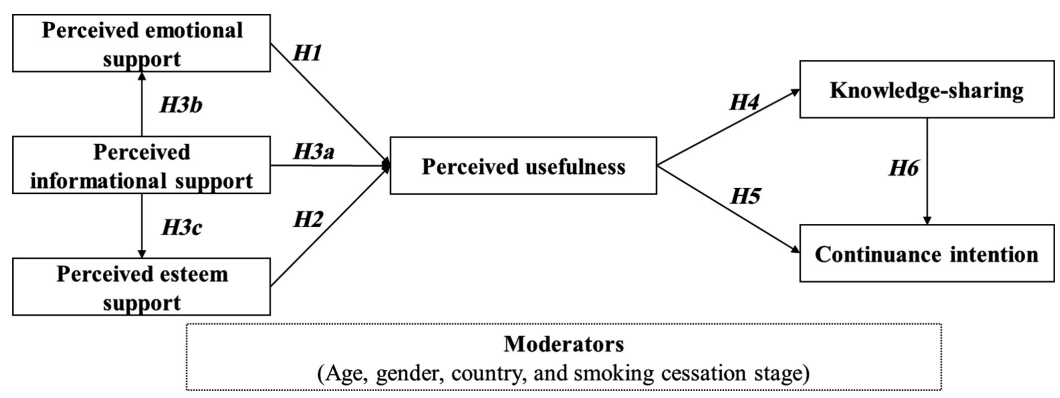

Figure 1.

The proposed research model 
INTR 32,7

\section{6}

their emotional stability by reducing such signs of emotional distress as anxiety and sorrow (Huang et al., 2019). Smokers who are trying to kick the habit often feel disappointed over their relapses and become anxious about the repeated failure. Smoking cessation OHCs offer a friendly environment in which smokers can disclose their negative feelings and ask for emotional support from people who have experienced similar situations (Huang et al., 2019; Zhang and Yang, 2015). Members of a smoking cessation $\mathrm{OHC}$ can receive empathy from peers who truly understand their negative emotions related to the smoking cessation process. In addition, users can obtain encouragement from other users that bolster their confidence in achieving abstinence. Moreover, the anonymity and privacy protections developed for smoking cessation OHCs allow freely sharing personal emotions without many security or privacy risks. Emotional support from these OHCs may assist in users' efforts to reduce the stress they face on the smoking cessation journey and to restore their emotional stability (Granado-Font et al., 2018; Rocheleau et al., 2015; Zhang and Yang, 2015). A positive correlation between emotional support and smoking cessation success has been reported in the context of telephone-based interventions (Burns et al., 2014), providing further reason to expect perceived emotional support from smoking cessation OHCs to help smokers regain emotional stability, which may lead to greater success in kicking the habit. Accordingly, the more emotional support users can obtain from the smoking cessation $\mathrm{OHC}$, the more useful we would expect them to find the $\mathrm{OHC}$. We formed the following hypothesis:

H1. Perceived emotional support is positively associated with the PU of a smoking cessation $\mathrm{OHC}$.

Esteem support provides compliments and releases from blame (Cutrona and Suhr, 1992). This support can help smokers elevate their belief in themselves and their abilities with regard to quitting smoking (Deng and Liu, 2017; Huang et al., 2014). Specifically, users of smoking cessation $\mathrm{OHCs}$ often receive congratulations and positive feedback when sharing their achievements (e.g. a month of being tobacco-free). This can help them cultivate a positive self-image and believe in their ability to quit smoking and in their capabilities for doing so. Furthermore, peers' expressions of forgiveness might alleviate users' feelings of guilt associated with relapse and motivate them to move past failures without blaming themselves unfairly. Studies have identified compliments as one type of partner support that promotes success in smoking cessation in offline settings (Cohen and Lichtenstein, 1990). As for online contexts in general, the literature suggests that esteem support is a social factor that supports health-related behavior changes, such as increased physical activity (Cavallo et al., 2014). Therefore, it is reasonable to expect perceived esteem support from a smoking cessation $\mathrm{OHC}$ to have positive effects on users' perceptions of the usefulness of the OHC. The more esteem support one receives from the smoking cessation $\mathrm{OHC}$, the more useful that $\mathrm{OHC}$ is perceived to be. We developed the following hypothesis accordingly:

H2. Perceived esteem support is positively associated with the PU of a smoking cessation $\mathrm{OHC}$.

Scholars have identified informational support as another major type of social support in smoking cessation OHCs (Granado-Font et al., 2018; Rocheleau et al., 2015). This form of support provides users with information on problem-solving (Huang et al., 2019). Users of a smoking cessation $\mathrm{OHC}$ may receive information on the benefits of quitting and the negative consequences of continuing to smoke (Granado-Font et al., 2018; Rocheleau et al., 2015; Zhang and Yang, 2015). This might assist smokers in developing firmer intentions to stop smoking and get ready for truly quitting (World Health Organization, 2014). Additionally, users can get suggestions, such as tips on coping with cravings and withdrawal symptoms, and read personal success stories addressing how to quit (Granado-Font et al., 2018; Rocheleau et al., 2015; Zhang and Yang, 2015). With this support, smokers may gain skills for quitting and 
better optimize their quitting strategies and plans. In addition, unlike general guidelines produced by professionals, the informational support in smoking cessation OHCs is largely based on real-world experiences so may better match individual smokers' practical needs. Informational support from smoking cessation OHCs may help users prepare, plan and act to stop their tobacco use. Therefore, it is reasonable to expect that the perceived informational support from the $\mathrm{OHC}$ will lead them to perceive the $\mathrm{OHC}$ as useful. The more informational support one can receive from it, the more useful it is perceived to be. Accordingly, we hypothesized thus:

H3a. Perceived informational support is positively associated with the PU of a smoking cessation $\mathrm{OHC}$.

Psychology literature shows that the information individuals have received can affect their emotions (Joseph et al., 2020; Westermann et al., 1996). For instance, Zupan and Babbage (2017) found that reading information (e.g. narratives or stories) can elicit emotions such as sadness, anger and happiness. Familiar events and situations depicted in written stories lead readers to sympathize with the characters, thereby evoking emotional responses (Oatley, 1999; Zupan and Babbage, 2017). Much of the informational support received in smoking cessation OHCs takes this form - not only smoking cessation tips, advice and facts, but also personal experience and stories (Cheung et al., 2017), which may trigger emotional reactions and help cultivate experiences of emotional support (Derks et al., 2008; Verheyen and Goritz, 2009). For instance, personal stories about quitting posted by other members of the $\mathrm{OHC}$ may remind users that they are not alone in their struggle and encourage them to feel a sense of companionship. Meanwhile, others' achievements and victories might also support rebuilding a user's confidence in continuing the fight against nicotine addiction, having the effects of esteem support in smoking cessation OHCs. At the same time, those who benefit from such informational support may give supportive feedback to its providers, expressing congratulations and thanks in return. These factors led us to expect perceived informational support to have an influence on perceived emotional and esteem support, so we proposed the following hypotheses:

$H 3 b$. Perceived informational support is positively associated with perceived emotional support in a smoking cessation $\mathrm{OHC}$.

H3c. Perceived informational support is positively associated with perceived esteem support in a smoking cessation OHC.

In the literature, some have argued that PU is the primary determinant of knowledgesharing behavior in online communities. For instance, Yuan et al. (2016) found that PU affected it in the context of online travel-oriented communities. In addition, some work has found that PU is the predominant driver of users' intention to continue using the given IS (Bhattacherjee, 2001). Hence, we expected to find that PU affects both continuance intention and knowledge-sharing behavior in smoking cessation $\mathrm{OHCs}$, and we proposed the following two hypotheses:

H4. PU is positively associated with users' knowledge sharing related to smoking cessation OHCs.

H5. PU is positively associated with users' intention to continue using the smoking cessation $\mathrm{OHC}$.

Prior literature highlights contributors to different post-IS-adoption behaviors, among them continuance intention and knowledge sharing, but minimal attention has been paid to associations between these distinct postadoption behaviors. Li and Liu (2014) have suggested that there is value in investigating these relationships for purposes of examining their
Perceived usefulness of smoking cessation $\mathrm{OHC}$ 
INTR 32,7

\section{8}

possible interdependence. Studying online auction communities, Wang and Chiang (2009) found that users who are more engaged in online communities (e.g. asking and/or answering questions) are more likely to continue using them. Therefore, it is reasonable to argue that the more knowledge users of smoking cessation OHCs share (whether sharing tips/advice/ experience or asking/answering questions), the more likely they will be to keep using the OHCs. We developed this hypothesis:

H6. Users' knowledge sharing is positively associated with their intention to continue using the smoking cessation $\mathrm{OHC}$.

Finally, considering possible effects of user characteristics such as age and gender as moderators has been recommended for anyone testing whether social support affects smoking cessation outcomes (Westmaas et al., 2010). Furthermore, research indicates that an additional factor, the individual's stage on the smoking cessation journey, has an association with social support in $\mathrm{OHC}$ contexts (Ploderer et al., 2013). Since we collected our empirical data in two countries with different cultural backgrounds, we considered the country as another possible moderator. We hypothesized that country, age, gender and smoking cessation stage moderate the proposed relationships in our model.

\section{Research method}

\subsection{Development of the measurement technique}

To guarantee the reliability and validity of the measurements for each construct in the proposed model, we employed previously validated instruments. The items for each construct were reworded for the context of smoking cessation OHCs. A five-point scale, ranging from " 1 = strongly disagree" to " $5=$ strongly agree," was used to measure all the construct items in the study. The source items for perceived informational support and perceived emotional support were informed by the research of Liang et al. (2011), the measurement items for perceived esteem support were adapted from work by Oh et al. (2013), PU and continuance intention were measured with items adapted from Bhattacherjee (2001) and items for knowledge sharing were adapted from the work of Hsu et al. (2007). The Appendix presents details of the construct items.

\subsection{The data-collection process}

Two nonprofit smoking cessation OHCs, one in Finland (Stumppi.fi) and the other in China (a smoking cessation bar on Baidu Post Bar), were selected for this research. Even though the smoking cessation OHCs operated in very different countries and were hosted by separate organizations, they showed some similarities in platform structure and functions. Both OHCs provided users with basic functions, such as starting a new discussion, submitting questions to seek help, commenting or replying in a discussion thread and sending private messages, and both are easy to use.

We employed our online survey to collect the data after having received ethics approval from the corresponding author's home university. The survey questionnaire for collecting empirical data was developed in English and then translated into Finnish and Chinese. Then, IS researchers who are native speakers of the respective languages reviewed the questionnaire in all three variants to verify the validity of the content and its translation. After this, we conducted a pilot study with 20 users of Stumppi.fi to test the questionnaire in Finnish. We modified the questionnaires in all three languages further on the basis of their feedback.

The full-scale online survey was launched on November 23, 2018 in China and December 17, 2018 in Finland. We recruited participants by making the questionnaire available via the two target smoking cessation OHCs. In all, 235 users had responded by April 30, 2019 (48 in 
Finland and 187 in China). Each respondent received an incentive for participating in the online survey.

After exclusion of replies that indicated an unwillingness to participate in the survey $(2$ in Finland, 48 in China) and unreliable replies, such as ones with the same answer option marked for all measurement items ( 12 in China), we had 173 forms as a valid sample for data analysis.

All respondents were smokers at different stages in smoking cessation. As for the sample's demographic breakdown, most respondents were between 25 and 44 years old $(67.6 \%)$, and $37.0 \%$ were female, $59.5 \%$ were male and $3.5 \%$ concealed their gender. Table 3 presents all respondents' demographic information and smoking cessation stage.

\subsection{Measurement invariance, common-method variance and collinearity}

Because the data were collected from different smoking cessation OHCs, in two countries, we conducted an invariance test to check whether the construct measurements were understood similarly by the two samples, following the measurement invariance of composite models (MICOM) assessment procedure proposed by Henseler et al. (2016b). The results of permutation testing show that all $c$ values, the difference in mean values and the variance of composites between the two countries fall between the upper and lower bound for the $95 \%$ confidence interval, as recommended by Henseler et al. (2016b). Thus, the testing established that we achieved measurement invariance, indicating that we could safely pool the data from the two sources and proceed with the analysis.

We used Harman's single-factor test (Podsakoff et al., 2003) to check for common-method variance (CMV). The highest total variance for any factor is $45.8 \%$, which is below the recommended maximum of $50 \%$ (Podsakoff et al., 2003), thereby indicating minimal concern about CMV. Further, we measured collinearity via partial least squares (PLS), following the suggestion of Kock and Lynn (2012). All variance inflation factors from the full collinearity test are below the recommended upper limit of 3.3 (Kock and Lynn, 2012), so the research model is free of collinearity.

\subsection{Data analysis}

We used the PLS implementation of SmartPLS 3.0 to test both the measurement model (this involved assessment of convergent validity and discriminant validity) and the structure model. To test convergent validity (Chin, 1998; Hulland, 1999; Tenenhaus et al., 2005), we used

\begin{tabular}{llrr}
\hline Variable & Items & Count & Percentage (\%) \\
\hline \multirow{2}{*}{ Country } & Finland & 46 & 26.6 \\
& China & 127 & 73.4 \\
Gender & Male & 103 & 59.5 \\
& Female & 64 & 37.0 \\
Age & Unwilling to disclose & 6 & 3.5 \\
& $15-24$ & 17 & 9.8 \\
& $25-44$ & 117 & 67.6 \\
Stage in ceasing to smoke & $45-65$ & 35 & 20.2 \\
& $>65$ & 4 & 2.3 \\
& Precontemplation & 4 & 2.3 \\
& Contemplation & 45 & 26.0 \\
& Preparation & 19 & 11.0 \\
& Action & 40 & 23.1 \\
& Maintenance & 50 & 28.9 \\
& Termination & 15 & 8.7
\end{tabular}

Perceived usefulness of smoking cessation $\mathrm{OHC}$ 
INTR 32,7

\section{0}

Table 4.

Results from confirmatory factor analysis the factor loading for each item, composite reliability (CR) and average variance extracted (AVE) for each construct. We removed two items, PEMS3 and PIS1, because their loadings were lower than the recommended minimum. As Table 4 shows, each item's factor loading exceeded 0.70, and the AVE and CR figures met the recommended criteria: the threshold values are 0.5 and 0.7 (Chin, 1998; Fornell and Larcker, 1981), respectively. This indicates adequate convergent validity.

To evaluate discriminant validity, we calculated the square root of the AVE for all constructs in the research model. We then conducted a comparison between the loading of each item for an associated construct and its cross-loadings on other constructs. For each construct, the value of the square root of the AVE is higher than the correlation with other constructs (See Table 5). As shown in Table 6, the factor loading of each construct item for the relevant construct is higher than the cross-loadings on the other constructs. Thus, the discriminant validity of all constructs in our proposed model is supported (Chin, 1998).

\begin{tabular}{|c|c|c|c|c|c|}
\hline Construct & Item & Factor loading & Cronbach's alpha & $\mathrm{CR}$ & AVE \\
\hline \multirow[t]{3}{*}{$\mathrm{CI}$} & CI1 & 0.872 & \multirow[t]{3}{*}{0.807} & \multirow[t]{3}{*}{0.886} & \multirow[t]{3}{*}{0.723} \\
\hline & $\mathrm{CI} 2$ & 0.806 & & & \\
\hline & CI3 & 0.870 & & & \\
\hline \multirow{3}{*}{ PEMS } & PEMS1 & 0.866 & \multirow[t]{3}{*}{0.843} & \multirow[t]{3}{*}{0.905} & \multirow[t]{3}{*}{0.761} \\
\hline & PEMS2 & 0.851 & & & \\
\hline & PEMS4 & 0.899 & & & \\
\hline \multirow[t]{3}{*}{ PESS } & PESS1 & 0.812 & \multirow[t]{3}{*}{0.822} & \multirow[t]{3}{*}{0.894} & \multirow[t]{3}{*}{0.738} \\
\hline & PESS2 & 0.865 & & & \\
\hline & PESS3 & 0.897 & & & \\
\hline \multirow{2}{*}{ PIS } & $\begin{array}{l}\text { PIS2 } \\
\text { PIS }\end{array}$ & 0.868 & \multirow[t]{2}{*}{0.670} & \multirow[t]{2}{*}{0.858} & \multirow[t]{2}{*}{0.752} \\
\hline & PIS3 & 0.866 & & & \\
\hline \multirow{4}{*}{ KS } & KS1 & 0.926 & \multirow[t]{4}{*}{0.935} & \multirow[t]{4}{*}{0.954} & \multirow[t]{4}{*}{0.838} \\
\hline & KS2 & 0.898 & & & \\
\hline & KS3 & 0.923 & & & \\
\hline & KS4 & 0.913 & & & \\
\hline \multirow{4}{*}{$\mathrm{PU}$} & PU1 & 0.821 & \multirow[t]{4}{*}{0.799} & \multirow[t]{4}{*}{0.870} & \multirow[t]{4}{*}{0.626} \\
\hline & PU2 & 0.842 & & & \\
\hline & PU3 & 0.785 & & & \\
\hline & PU4 & 0.711 & & & \\
\hline
\end{tabular}

Note(s): CI, continuance intention; PEMS, perceived emotional support; PESS, perceived esteem support; PIS, perceived informational support; KS, knowledge sharing; PU, perceived usefulness; CR, composite reliability; AVE, average variance extracted
Table 5.

Correlations and square roots of AVE

\begin{tabular}{lcccccr}
\hline & CI & PEMS & PESS & PIS & KS & PU \\
\hline CI & 0.850 & & & & & \\
PEMS & 0.428 & 0.872 & & & & \\
PESS & 0.507 & 0.740 & 0.859 & & & \\
PIS & 0.460 & 0.743 & 0.766 & 0.867 & & \\
KS & 0.470 & 0.578 & 0.565 & 0.611 & 0.915 & \\
PU & 0.541 & 0.631 & 0.660 & 0.604 & 0.572 & 0.791
\end{tabular}

Note(s): CI, continuance intention; PEMS, perceived emotional support; PESS, perceived esteem support; PIS, perceived informational support; KS, knowledge sharing; PU, perceived usefulness 


\begin{tabular}{lcccccr}
\hline & CI & PEMS & PESS & PIS & KS & PU \\
\hline CI1 & 0.872 & 0.392 & 0.430 & 0.396 & 0.373 & 0.460 \\
CI2 & 0.806 & 0.364 & 0.489 & 0.387 & 0.383 & 0.436 \\
CI3 & 0.870 & 0.338 & 0.381 & 0.390 & 0.438 & 0.482 \\
PEMS1 & 0.395 & 0.866 & 0.646 & 0.673 & 0.529 & 0.624 \\
PEMS2 & 0.330 & 0.851 & 0.632 & 0.617 & 0.486 & 0.489 \\
PEMS4 & 0.390 & 0.899 & 0.657 & 0.650 & 0.494 & 0.528 \\
PESS1 & 0.428 & 0.630 & 0.812 & 0.647 & 0.521 & 0.480 \\
PESS2 & 0.421 & 0.639 & 0.865 & 0.660 & 0.468 & 0.633 \\
PESS3 & 0.458 & 0.639 & 0.897 & 0.668 & 0.471 & 0.578 \\
PIS2 & 0.414 & 0.666 & 0.648 & 0.868 & 0.481 & 0.525 \\
PIS3 & 0.384 & 0.623 & 0.681 & 0.866 & 0.579 & 0.523 \\
KS1 & 0.460 & 0.549 & 0.526 & 0.558 & 0.926 & 0.534 \\
KS2 & 0.377 & 0.498 & 0.517 & 0.533 & 0.898 & 0.511 \\
KS3 & 0.438 & 0.566 & 0.522 & 0.585 & 0.923 & 0.535 \\
KS4 & 0.440 & 0.499 & 0.503 & 0.561 & 0.913 & 0.513 \\
PU1 & 0.432 & 0.423 & 0.451 & 0.420 & 0.458 & 0.821 \\
PU2 & 0.497 & 0.493 & 0.535 & 0.459 & 0.504 & 0.842 \\
PU3 & 0.380 & 0.548 & 0.594 & 0.585 & 0.488 & 0.785 \\
PU4 & 0.400 & 0.533 & 0.499 & 0.439 & 0.347 & 0.711 \\
Note(s): CI, continuance intention; PEMS, perceived emotional support;PESS, perceived esteem support; PIS, &
\end{tabular}

Note(s): CI, continuance intention; PEMS, perceived emotional support; PESS, perceived esteem support; PIS, perceived informational support; KS, knowledge sharing; PU, perceived usefulness

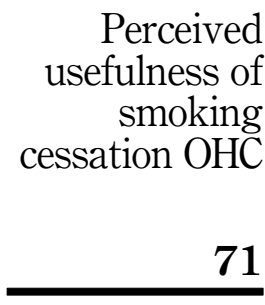

We tested the predictive validity of the model by computing the Stone-Geisser $Q^{2}$ (Geisser, 1974; Hair et al., 2017; Stone, 1974), which was measured by means of SmartPLS 3.0's blindfolding technique. The $Q^{2}$ for knowledge sharing was 0.255 , the $Q^{2}$ for continuance intention was 0.221 and the $Q^{2}$ for PU was 0.279 , indicating good predictive relevance.

Finally, we tested the goodness of fit by measuring the standardized root mean square residual or SRMR (Henseler et al., 2016a). The result was 0.064, which is lower than the maximum acceptable value of 0.08 proposed by Hu and Bentler (1999). Our model showed a good fit.

We applied the bootstrapping procedure of SmartPLS 3.0 to test the structural model, including the path significance and the hypotheses' effects. The overall explanatory power and estimated path coefficients are presented in Figure 2. As postulated, perceived emotional support $(\beta=0.267, p<0.05)$ and perceived esteem support $(\beta=0.367, p<0.001)$ had a significant positive correlation with PU. We did not find a significant association between

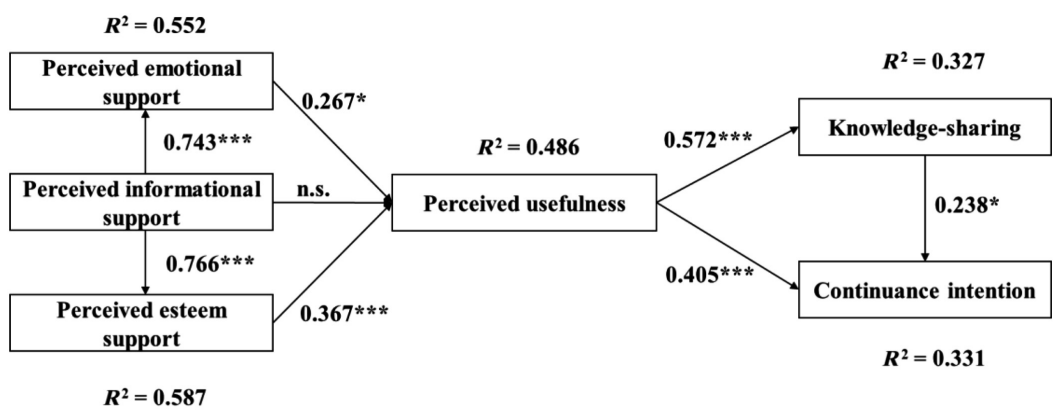

Note(s): ${ }^{* * *} p<0.001 ; * p<0.05$; n.s., not significant

The structural model without moderators 
INTR 32,7 perceived informational support and PU, but the former was significantly correlated with perceived emotional support $(\beta=0.743, p<0.001)$ and perceived esteem support $(\beta=0.766$, $p<0.001)$. PU showed a significant positive correlation both with knowledge sharing $(\beta=0.572, p<0.001)$ and with continuance intention $(\beta=0.405, p<0.001)$. Finally, knowledge sharing showed a significant association with continuance intention $(\beta=0.238$, $p<0.05$ ). Therefore, H1, H2, H3b, H3c, H4, H5 and H6 are supported. Our model explains $48.6 \%$ of the variation in the PU of smoking cessation $\mathrm{OHCs}, 32.7 \%$ of knowledge sharing, $33.1 \%$ of continuance intention, $55.2 \%$ of perceived emotional support and $58.7 \%$ of perceived esteem support.

\subsection{Moderation analysis}

To test for moderating effects of age, gender, country and smoking cessation stage, we performed multigroup analysis (MGA) to investigate whether the paths' strengths differ with the user group, after evaluating the measurement invariance by means of the aforementioned MICOM procedure.

Since most respondents were aged 25-44 $(N=117)$ and the numbers in other age bands were relatively small, we balanced the samples in size by dividing the respondents into two groups: group A includes those aged 25-44, and group B includes all those under 25 or over 44. Regarding the smoking cessation stage, we divided the sample into three groups in line with the six stages on the journey described by Prochaska and Velicer (1997), (1) before-action users, encompassing all those intending to quit but not having acted on this intention yet and covering the contemplation and preparation stages; (2) in-action users, for those who had entered a stage of action; and (3) after-action users, covering those who had not smoked for at least six months - individuals in the maintenance or temptation stage. Note that the four responses from those in the precontemplation stage, without an intention to quit smoking, were excluded from the analysis.

As Table 7 illustrates, we verified full measurement invariance between Finnish and Chinese respondents and also with regard to different age groups. For the gender and smoking cessation stage, partial invariance was identified. Therefore, performing MGA can be considered acceptable in this case (Henseler et al., 2016b).

No significant difference was found between Finnish and Chinese users (see Table 8). A significant difference did appear between the two age classes, however, with specific regard to the relationship between knowledge sharing and continuance intention (see Table 9). Also, as Table 10, on gender, indicates, we found a significant difference between male and female users for the connection between perceived emotional support and PU: perceived emotional support was a significant driver of PU for female users $\beta=0.599$, $p<0.001$ ) but not for male users.

As Table 11 shows, we found a connection between perceived emotional support and PU for before-action users, and perceived esteem support was linked to PU for after-action users. Also, PU showed a significant correlation with knowledge sharing no matter the user's stage in the smoking cessation process. For before-action and in-action respondents alike, PU was significantly correlated with continuance intention, but knowledge sharing displayed a significant connection to continuance intention among only those users in the afteraction group.

\section{Discussion}

Our findings on the antecedents to the PU of smoking cessation $\mathrm{OHCs}$ and on its consequences raise several points that are of interest.

Firstly, perceived emotional support emerged as a determinant of the PU, particularly for users who want to quit smoking but have taken no action thus far. One possible explanation 


\begin{tabular}{|c|c|c|c|c|c|}
\hline Group & Composite & $\begin{array}{l}c \text { value } \\
(=1)\end{array}$ & $\begin{array}{l}95 \% \text { confidence } \\
\text { interval }\end{array}$ & $\begin{array}{l}\text { Compositional } \\
\text { invariance }\end{array}$ & $\begin{array}{l}\text { Equal mean values } \\
\text { and variances }\end{array}$ \\
\hline Finland vs. & $\mathrm{CI}$ & 0.993 & {$[0.987 ; 1.000]$} & Yes & Yes \\
\hline \multirow[t]{5}{*}{ China } & PEMS & 1.000 & {$[0.998 ; 1.000]$} & Yes & Yes \\
\hline & PESS & 0.999 & {$[0.997 ; 1.000]$} & Yes & Yes \\
\hline & PIS & 0.999 & {$[0.995 ; 1.000]$} & Yes & Yes \\
\hline & $\mathrm{KS}$ & 1.000 & {$[0.997 ; 1.000]$} & Yes & Yes \\
\hline & $\mathrm{PU}$ & 0.997 & {$[0.991 ; 1.000]$} & Yes & Yes \\
\hline \multirow{6}{*}{$\begin{array}{l}\text { Age group A } \\
\text { vs. B }\end{array}$} & $\mathrm{CI}$ & 0.999 & {$[0.990 ; 1.000]$} & Yes & Yes \\
\hline & PEMS & 0.999 & {$[0.999 ; 1.000]$} & Yes & Yes \\
\hline & PESS & 1.000 & {$[0.997 ; 1.000]$} & Yes & Yes \\
\hline & PIS & 0.999 & {$[0.996 ; 1.000]$} & Yes & Yes \\
\hline & $\mathrm{KS}$ & 0.999 & {$[0.999 ; 1.000]$} & Yes & Yes \\
\hline & $\mathrm{PU}$ & 0.997 & {$[0.994 ; 1.000]$} & Yes & Yes \\
\hline \multirow[t]{6}{*}{ Male vs. female } & $\mathrm{CI}$ & 0.997 & {$[0.991 ; 1.000]$} & Yes & Yes \\
\hline & PEMS & 1.000 & {$[0.999 ; 1.000]$} & Yes & Yes \\
\hline & PESS & 1.000 & {$[0.997 ; 1.000]$} & Yes & Yes \\
\hline & PIS & 1.000 & {$[0.997 ; 1.000]$} & Yes & No \\
\hline & $\mathrm{KS}$ & 0.999 & {$[0.999 ; 1.000]$} & Yes & No \\
\hline & $\mathrm{PU}$ & 0.999 & {$[0.994 ; 1.000]$} & Yes & No \\
\hline \multirow{6}{*}{$\begin{array}{l}\text { Before-action vs. } \\
\text { in-action }\end{array}$} & $\mathrm{CI}$ & 0.996 & {$[0.983 ; 1.000]$} & Yes & Yes \\
\hline & PEMS & 1.000 & {$[0.998 ; 1.000]$} & Yes & Yes \\
\hline & PESS & 0.998 & {$[0.996 ; 1.000]$} & Yes & Yes \\
\hline & PIS & 0.999 & {$[0.995 ; 1.000]$} & Yes & Yes \\
\hline & KS & 0.998 & {$[0.997 ; 1.000]$} & Yes & Yes \\
\hline & $\mathrm{PU}$ & 0.995 & {$[0.995 ; 1.000]$} & Yes & Yes \\
\hline \multirow{6}{*}{$\begin{array}{l}\text { In-action vs. } \\
\text { after-action }\end{array}$} & $\mathrm{CI}$ & 0.991 & {$[0.985 ; 1.000]$} & Yes & No \\
\hline & PEMS & 0.999 & {$[0.997 ; 1.000]$} & Yes & Yes \\
\hline & PESS & 0.999 & {$[0.993 ; 1.000]$} & Yes & Yes \\
\hline & PIS & 1.000 & {$[0.993 ; 1.000]$} & Yes & Yes \\
\hline & $\mathrm{KS}$ & 0.999 & {$[0.998 ; 1.000]$} & Yes & Yes \\
\hline & $\mathrm{PU}$ & 0.994 & {$[0.967 ; 1.000]$} & Yes & Yes \\
\hline \multirow{6}{*}{$\begin{array}{l}\text { Before-action vs. } \\
\text { after-action }\end{array}$} & $\mathrm{CI}$ & 0.989 & {$[0.987 ; 1.000]$} & Yes & Yes \\
\hline & PEMS & 1.000 & {$[0.998 ; 1.000]$} & Yes & Yes \\
\hline & PESS & 1.000 & {$[0.997 ; 1.000]$} & Yes & Yes \\
\hline & PIS & 0.999 & {$[0.996 ; 1.000]$} & Yes & Yes \\
\hline & KS & 0.999 & {$[0.998 ; 1.000]$} & Yes & No \\
\hline & $\mathrm{PU}$ & 0.994 & {$[0.992 ; 1.000]$} & Yes & Yes \\
\hline
\end{tabular}

Note(s): CI, continuance intention; PEMS, perceived emotional support; PESS, perceived esteem support; PIS, perceived informational support; KS, knowledge sharing; PU, perceived usefulness

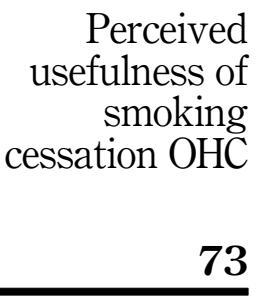

\begin{tabular}{|c|c|c|c|c|}
\hline & Comparison by country & \multicolumn{2}{|c|}{ Path coefficients of separate structural models } & \\
\hline & China vs. Finland & China $(N=127)$ & Finland $(N=46)$ & \\
\hline H1 & n.s & n.s & $0.574^{* * * *}$ & \\
\hline $\mathrm{H} 2$ & n.s & $0.422 * *$ & n.s & \\
\hline H3a & n.s & n.s & n.s & \\
\hline $\mathrm{H} 3 \mathrm{~b}$ & n.s & $0.765^{* * * *}$ & $0.658 * * *$ & \\
\hline $\mathrm{H} 3 \mathrm{c}$ & n.s & $0.779 * * * *$ & $0.647 * * * *$ & \\
\hline $\mathrm{H} 4$ & n.s & $0.541^{* *}$ & $0.353^{* * * *}$ & \\
\hline H5 & n.s & $0.440 * * *$ & $0.309 *$ & Table 8. \\
\hline $\mathrm{H} 6$ & n.s & $0.268^{*}$ & n.s & Results from testing \\
\hline \multicolumn{5}{|c|}{ Note(s): ${ }^{* * *}, p<0.001 ; * *, p<0.01 ; *, p<0.05 ;$ n.s., not significant } \\
\hline
\end{tabular}




\begin{tabular}{|c|c|c|c|c|}
\hline \multirow{3}{*}{$\begin{array}{l}\text { INTR } \\
32,7\end{array}$} & \multirow{3}{*}{\multicolumn{2}{|c|}{$\begin{array}{l}\text { Comparison by age group } \\
\text { Group A vs. group B }\end{array}$}} & & \\
\hline & & & \multicolumn{2}{|c|}{ Path coefficients of separate structural models } \\
\hline & & & Group A $(N=117)$ & Group B $(N=56)$ \\
\hline \multirow[b]{5}{*}{74} & H1 & n.s & n.s & 0.540 **** \\
\hline & $\mathrm{H} 2$ & n.s & $0.374^{*}$ & n.s \\
\hline & H3a & n.s & n.s & n.s \\
\hline & $\mathrm{H} 3 \mathrm{~b}$ & n.s & $0.758^{* * * *}$ & $0.716^{* * * *}$ \\
\hline & $\mathrm{H} 3 \mathrm{c}$ & n.s & $0.766^{* * * *}$ & $0.778 * * *$ \\
\hline \multirow{4}{*}{$\begin{array}{l}\text { Table } 9 \text {. } \\
\text { Results from testing } \\
\text { age as a moderator }\end{array}$} & $\mathrm{H} 4$ & n.s & $0.527 * * * *$ & $0.640 * * *$ \\
\hline & H5 & n.s & $0.348^{*}$ & $0.605^{* * * *}$ \\
\hline & $\mathrm{H} 6$ & $p<0.05$ & $0.378^{* * * *}$ & n.s \\
\hline & \multicolumn{4}{|c|}{$\operatorname{Note}(\mathbf{s}): * * *, p<0.001 ; *, p<0.05 ;$ n.s., not significant } \\
\hline
\end{tabular}

\begin{tabular}{|c|c|c|c|c|}
\hline & \multirow{2}{*}{\multicolumn{2}{|c|}{$\begin{array}{l}\text { Comparison by gender } \\
\text { Male vs. female }\end{array}$}} & \multicolumn{2}{|c|}{ Path coefficients of separate structural models } \\
\hline & & & Male $(N=103)$ & Female $(N=64)$ \\
\hline & H1 & $p<0.05$ & n.s & $0.599 * * *$ \\
\hline & $\mathrm{H} 2$ & n.s & $0.479 * * *$ & n.s \\
\hline & H3a & n.s & n.s & n.s \\
\hline & $\mathrm{H} 3 \mathrm{~b}$ & n.s & $0.770^{* * * *}$ & $0.692^{* * *}$ \\
\hline & $\mathrm{H} 3 \mathrm{c}$ & n.s & $0.799 * * * *$ & $0.689 * * *$ \\
\hline & $\mathrm{H} 4$ & n.s & $0.560^{* * *}$ & $0.543^{* * *}$ \\
\hline \multirow{3}{*}{$\begin{array}{l}\text { Table } 10 . \\
\text { Results from testing } \\
\text { gender as a moderator }\end{array}$} & H5 & n.s & $0.390^{*}$ & $0.339 *$ \\
\hline & $\mathrm{H} 6$ & n.s & $0.367^{*}$ & n.s \\
\hline & \multicolumn{4}{|c|}{ Note(s): $* * *, p<0.001 ; *, p<0.05$; n.s., not significant } \\
\hline
\end{tabular}

\section{Table 11.}

Results from testing the user's stage in smoking cessation as a moderator

\begin{tabular}{|c|c|c|c|c|c|c|}
\hline & \multicolumn{3}{|c|}{ Comparison by stage in smoking cessation } & \multicolumn{3}{|c|}{ Path coefficients of separate structural models } \\
\hline & $\begin{array}{l}\text { Before action } \\
\text { vs. in action }\end{array}$ & $\begin{array}{l}\text { In action vs. } \\
\text { after action }\end{array}$ & $\begin{array}{l}\text { Before action vs. } \\
\text { after action }\end{array}$ & $\begin{array}{l}\text { Before action } \\
\quad(N=64)\end{array}$ & $\begin{array}{l}\text { In action } \\
(N=40)\end{array}$ & $\begin{array}{l}\text { After action } \\
(N=65)\end{array}$ \\
\hline $\mathrm{H} 1$ & n.s & n.s & n.s & $0.387^{* *}$ & n.s & n.s \\
\hline $\mathrm{H} 2$ & n.s & n.s & n.s & n.s & n.s & $0.345^{*}$ \\
\hline H3a & n.s & n.s & n.s & n.s & n.s & n.s \\
\hline H3b & n.s & n.s & $p<0.05$ & $0.845^{* * * *}$ & $0.802 * * *$ & $0.623 * * *$ \\
\hline H3c & $p<0.05$ & n.s & $p<0.05$ & $0.887 * * *$ & $0.660 * * *$ & $0.705^{* * * *}$ \\
\hline H4 & n.s & n.s & $p<0.05$ & $0.737 * * * *$ & $0.645 * * *$ & $0.392 * * *$ \\
\hline H5 & n.s & $p<0.05$ & $p<0.001$ & $0.718^{* * * *}$ & $0.692 * * *$ & n.s \\
\hline $\mathrm{H} 6$ & n.s & $p<0.05$ & n.s & n.s & n.s & $0.404 * * * *$ \\
\hline \multicolumn{7}{|c|}{ Note(s): $* * *, p<0.001 ; * *, p<0.01 ; *, p<0.05 ;$ n.s., not significant } \\
\hline
\end{tabular}

is that those users are still hesitant to initiate actions in this regard and, hence, need encouragement or expressions of care from others, to dispel any misgivings about smoking cessation and to enhance their confidence in such actions. Also noteworthy is the gender difference we uncovered in the relationship between perceived emotional support and PU. A possible explanation for it being an antecedent to PU among female but not male users is that women value emotional support more than males do, particularly in stressful situations (Matud, 2004; Tamres et al., 2002). Female users of smoking cessation OHCs might be likely to view emotional support as crucial for reducing smoking-related stress than male users. Accordingly, when experiencing high levels of emotional support via a smoking cessation 
$\mathrm{OHC}$, female users are likely to perceive the smoking cessation $\mathrm{OHC}$ as useful for improving the outcome of their smoking cessation efforts.

Secondly, our findings suggest that perceived esteem support is another important antecedent to the PU of smoking cessation OHCs, especially for users who have been able to avoid smoking for at least six months. It may be that these users in particular are likely to blame themselves for repeated lapses, which can occur easily. Esteem support from others can reduce their self-blame, and positive feedback recognizing what they have achieved on the journey of quitting smoking may well enhance their self-confidence. Our findings in relation to this contribute significantly to the literature. Little prior research has examined the association between perceived esteem support and the PU of OHCs. This might be because most scholars focus on emotional support when considering the social support associated with users' personal emotions in OHCs and overlook the importance of esteem support.

Contrary to our hypothesis, perceived informational support did not emerge as an antecedent to the PU of the OHCs in our research context. This finding is at odds with research by $\mathrm{Wu}$ (2018), who identified informational support as an important driver of the PU of general OHCs. This discrepancy might arise from the indirect influences that perceived informational support exerts on PU, via the effects of both perceived emotional support and perceived esteem support on the PU of the smoking cessation OHCs. Indeed, the post hoc mediation analysis showed that the impact of perceived informational support on PU was fully mediated by perceived emotional support (direct effect $\beta=0.127, p>0.05$; indirect effect $\beta=0.199, p<0.05$ ) and by perceived esteem support (direct effect $\beta=0.127, p>0.05$; indirect effect $\beta=0.278, p<0.001$ ). The informational support experienced from smoking cessation OHCs may not always be adequate to enhance users' perception of the OHC's usefulness, since they can obtain similar information from alternative sources, such as online self-help materials or advice from doctors. In addition, informational support in smoking cessation OHCs might feed into users' perceptions of emotional and esteem support instead. For instance, reading other users' stories in a smoking cessation $\mathrm{OHC}$ may help to produce a sense of stress release in the course of smoking cessation and a sense of being cared for by other members of the smoking cessation OHC. Meanwhile, the stories of success shared by other users could also shore up their confidence in quitting smoking. Through these mechanisms, perceived informational support has an indirect influence on the PU of smoking cessation $\mathrm{OHCs}$ via perceived emotional support and perceived esteem support.

Fourthly, we found significant impacts of PU on both continuance intention and knowledge sharing. Our findings on the former relationship are consistent with those from research in the domains of online banking (Bhattacherjee, 2001), e-learning (Alraimi et al., 2015), e-government (Hamid et al., 2016) and general OHCs (Wu, 2018): The PU strongly influences users' intention to continue using the smoking cessation $\mathrm{OHC}$. Our findings on the association between PU and knowledge sharing are in line with prior research too, such as the work of Yuan et al. (2016). Looking at the context of online travel communities, they found that the PU positively influences knowledge sharing in said communities. In smoking cessation $\mathrm{OHCs}$, when users perceive the $\mathrm{OHC}$ to be useful for faring better with the smoking cessation process, they are more likely to continue using the $\mathrm{OHC}$ and contribute their knowledge to the $\mathrm{OHC}$.

Another important finding is that knowledge sharing exerts positive effects on continuance intention with regard to smoking cessation OHCs. Our results demonstrate that the more knowledge users share with the smoking cessation $\mathrm{OHC}$, the stronger their intention to continue using it. This might be explained by the fact that users who have devoted time and effort to sharing knowledge in a smoking cessation $\mathrm{OHC}$ tend to form a bond with it. Such connections may render them more likely to continue their use. Interestingly, an age difference was evident in the relationship between knowledge sharing and continuance intention. The two showed a correlation among users aged 25-44 but not
Perceived usefulness of smoking cessation OHC 
INTR 32,7

among those of other ages. There are several possible explanations. One is that those aged 25-44, who constitute the majority of users of smoking cessation OHCs, form a useencouraging psychological bond with the $\mathrm{OHC}$ via their knowledge-sharing activities, a bond perhaps fortified by attention to age-specific concerns. The other users, on the other hand, might not share much knowledge in these forums, with their need for social support being the main factor in their wish to keep using them.

Finally, we should discuss the differences connected with users' stage in quitting smoking with regard to the impacts of PU on continuance intention and knowledge sharing. Specifically, PU exerts stronger significant effects on the continuance intention of beforeaction users than on that of in-action users but no significant effects for after-action users in this regard, and significant differences are visible both between the in- and after-action group and between the before- and after-action group. These significant differences might be due to the following factors: Before-action users may be new to the smoking cessation OHC, turning to it as they seek further guidance and social support to prepare themselves and to translate their quitting intentions into specific actions. When before-action users view the smoking cessation $\mathrm{OHC}$ as useful, they have much stronger intentions to continue using it than in-action users; they know that they will need even more social support from it when they enter the action stage. Finally, though after-action users perceive smoking cessation OHCs as useful in supporting their long-term goals, they have already reached the goal of abstinence, so PU might not be a large factor in their continuing use of the smoking cessation OHC.

We also found significant stage-related differences when examining perceived informational support's effects on perceived emotional support and perceived esteem support. Specifically, it has its strongest influence on the former among before-action users $(\beta=0.845, p<0.001)$, followed by in-action users $(\beta=0.802, p<0.001)$ and then after-action users $(\beta=0.623, p<0.01)$; a significant difference exists between before- and after-action users. Obviously, after-action users have been members for some time and achieved abstinence. Though they can still get informational support from the $\mathrm{OHC}$, they are familiar with the guidance and tips most commonly provided, so the influence of perceived informational support on perceived emotional support is weaker for them than for the other users. Before-action users, in contrast, are in more need of informational support, to help them decide to move on to actions, than are in-action users. The informational support they receive from smoking cessation OHCs gives them a stronger sense of empathy, encouragement and so on. from the OHC's other users. Therefore, it may be little surprise that perceived informational support has bigger impacts on perceived emotional support for before-action users relative to in-action users, who have already received considerable informational support that assists them in quitting smoking. Hence, the information they keep receiving might not confer as much emotional support as before-action users - who are in great need of informational support - experience.

As for the impact of perceived informational support on perceived esteem support, the influence is strongest for before-action users $(\beta=0.887, p<0.001)$, followed by after-action users $(\beta=0.705, p<0.001)$ and then in-action users $(\beta=0.660, p<0.001)$. We found significant differences between before- and in-action users and between before- and afteraction users both. One possible explanation for these is that users at different stages differ in the social support they need, for overcoming different challenges. Those who intend to quit but have not yet acted need guidance and advice, to build their confidence for doing so; therefore, perceived informational support influences these users most strongly, with regard to perceived esteem support. Those who have already quit smoking have experienced difficulties in keeping this up and need information that maintains their confidence in their ability to stay smoking-free. Finally, perceived informational support affects perceived esteem support least for members of the in-action group, who have established their confidence in quitting smoking but have not experienced all the hardships of the process. 
Stage-related differences emerged in relation to knowledge sharing too, with PU having the strongest connection with it among before-action users $(\beta=0.737, p<0.001)$, then in-action users $(\beta=0.645, p<0.001)$ and after-action users $(\beta=0.392, p<0.001)$. We identified a significant difference between the before- and the after-action group. The users who had already abstained from smoking for at least six months perceived smoking cessation $\mathrm{OHCs}$ as useful for their success in quitting smoking, but they were less likely than other users to contribute knowledge to the $\mathrm{OHC}$. One possible reason is that successful quitters use such OHCs less often than others do.

When examining the relationship between the two postadoption behaviors, we found a positive correlation between knowledge sharing and continuance intention only for afteraction users, with a significant difference visible between the in- and the after-action group. It might be that users who have already abstained for a while have solid practical tips and advice for other users, based on their experience, and also share more knowledge in the smoking cessation $\mathrm{OHC}$, to demonstrate reciprocity and support the users and $\mathrm{OHC}$ that supported them on the path to quitting smoking. When they share more knowledge in the smoking cessation $\mathrm{OHC}$, they feel a strong bond with the group and a sense of solidarity, so they are more likely to keep using the $\mathrm{OHC}$.

\section{Conclusions}

\subsection{Theoretical contributions}

The research findings have several implications for scholarship. Firstly, we extended the application of social support theory to explain IS postadoption behaviors in the context of smoking cessation OHCs from the view of social support in explaining PU of smoking cessation OHCs. Our consideration for the roles of distinct components of social support in explaining IS postadoption behaviors enriches IS research from the view of the social support of smoking cessation OHCs in addressing societies' public-health and well-being issues.

Secondly, whereas prior literature on external factors affecting PU has almost exclusively taken a technological perspective (Zhang et al., 2012), our work enriches PU literature by employing social support theory to investigate the antecedents to the PU of smoking cessation OHCs. Our findings on perceived emotional and esteem support as two important determinants of $\mathrm{PU}$ in this context suggest that PU can be explained well from the perspective of social support, which is especially relevant in a smoking cessation $\mathrm{OHC}$ context. By looking at users' perceptions of emotional support and esteem support as factors in explaining PU in this specific context, we advance understanding of $\mathrm{PU}$ of such $\mathrm{OHCs}$ and provide evidence of the value of contextualizing the antecedents to PU from the social support view with regard to specific research settings.

Furthermore, our work contributes to social support theory through its investigation of the associations between distinct types of social support in smoking cessation OHCs. Our findings suggest that perceived informational support is a prerequisite for perceived emotional support and perceived esteem support in such OHCs. Though perceived informational support has no direct impact on PU, it exerts an indirect influence on the smoking cessation OHC's PU via perceived emotional and esteem support. With this new empirical insight, we offer a plausible explanation of how specific types of social support trigger users' perceptions as to the PU of smoking cessation OHCs. The findings on the relationships between perceived informational support and perceived emotional and esteem support also provide a comprehensive understanding of the role of informational support in these OHCs from a social support perspective.

The postadoption literature also benefits from our theory-grounded insights. While previous studies investigated the determinants of continuance intention (e.g. Song et al., 2018; Wu, 2018) and of knowledge sharing separately (e.g. Yan et al., 2016; Zhang et al., 2020; Zhang et al., 2017), our study incorporated these two postadoption behaviors into a single research

Perceived usefulness of smoking cessation $\mathrm{OHC}$ 
INTR 32,7

model in the context of smoking cessation OHCs. Our findings related to how PU affects different postadoption behaviors (e.g. continuance intention and knowledge sharing) and the relationship between these distinct postadoption behaviors in the context of smoking cessation $\mathrm{OHCs}$ demonstrate that intentions to continue using such an $\mathrm{OHC}$ could be strengthened via knowledge-sharing activities. This study provides further evidence that knowledge-sharing behavior can trigger users' continuance intention with regard to smoking cessation $\mathrm{OHCs}$ while also suggesting that IS continuance research should consider the impacts of additional postadoption behaviors (knowledge sharing and others) on continuance intention, not merely users' motivations for continuance intention toward the IS.

Our final key theoretical contribution is related to the gender differences in the antecedents to PU and the moderating effects of smoking cessation stage on the consequences of PU. These findings highlight the crucial roles of user-specific factors (i.e. gender and smoking cessation stage) in explaining $\mathrm{PU}$ in such $\mathrm{OHC}$ and for bringing new insights that can advance our understanding of the antecedents and consequences of PU for particular user groups in this specific context and others. In other words, this study provides further empirical evidence that user-specific factors are closely associated with user perceptions of the usefulness of smoking cessation OHCs and their postadoption behavior regarding such $\mathrm{OHC}$ while also suggesting that research on smoking cessation $\mathrm{OHCs}$ should consider the role of user-specific factors when investigating users' postadoption behaviors regarding such $\mathrm{OHCs}$, not only the usefulness of such $\mathrm{OHCs}$.

\subsection{Practical implications}

There are several practical implications also, principally for those managing and running smoking cessation $\mathrm{OHCs}$. Our findings implying that PU affects continuance intention and knowledge sharing enable us to recommend that smoking cessation $\mathrm{OHC}$ service providers promote retention of users and sharing of knowledge by enhancing user perceptions of the usefulness of the smoking cessation OHCs. Specifically, our finding that perceived emotional and esteem support are antecedents to PU implies that smoking cessation $\mathrm{OHC}$ service providers should focus on their strategies and approaches for facilitating users' perceptions of emotional and esteem support in smoking cessation OHCs. For instance, smoking cessation $\mathrm{OHC}$ administrators should use warm and caring language when answering inquiries and also recommend users of such OHCs to apply warm messages in their communications with others to provide emotional support to other users. They can also offer templates expressing empathy and encouragement for users to use when they respond to other users. Users may find it more convenient to make selections from predefined message starters than to type out messages of emotional and esteem support from scratch.

Another recommendation, informed by the findings on the indirect impact of perceived informational support on PU, is that smoking cessation OHC service providers should continue to encourage information and knowledge sharing in these OHCs.

Since users in different stages on the smoking cessation journey differ in their needs for social support and their perceptions of the PU of the $\mathrm{OHC}$, the service providers could offer differential social support, tailored to stage-specific needs, thereby nurturing knowledge sharing and intentions to continue using the smoking cessation OHC. For instance, we found that perceived emotional support has a positive influence on $\mathrm{PU}$ for users who intend to quit smoking but have taken no action thus far. The findings suggest that it is crucial to provide these users with encouragement or expressions of care in online interactions in smoking cessation OHCs, which might meet their needs and enhance their perceptions of the usefulness of smoking cessation OHCs in support their quitting of smoking.

One of the most important stage-specific practical implications arises from the association between knowledge sharing and continuance intention among the after-action users. 
This link suggests that smoking cessation $\mathrm{OHC}$ service providers should encourage users at this stage on the journey to share more knowledge in the $\mathrm{OHC}$, thereby not only strengthening their intention to continue using the smoking cessation $\mathrm{OHC}$ but also producing informational support for other users.

\section{Limitations and paths for future research}

This study has several limitations, which represent directions for future research. Firstly, since we limited our consideration of the antecedents to the PU of smoking cessation OHCs to social-support exchange behavior, some other external determinants of PU could be investigated further. Research could examine the role of companionship activities in determining the PU of smoking cessation $\mathrm{OHCs}$ and evaluate the associated differences with regard to exchanging of social support. Secondly, while we examined how social support affects two distinct postadoption behaviors indirectly via PU, we did not test the direct impact of social support on these behaviors of smoking cessation OHC users. Therefore, future research could usefully investigate whether particular types of social support directly affect these two postadoption behaviors - and others. While we limited ourselves to investigating only two consequences of the PU of smoking cessation $\mathrm{OHCs}$, further work could test whether our proposed model is appropriate for studying postadoption behaviors additional to continuance intention and knowledge sharing, such as governance- and recommendationrelated outcomes (Zou et al., 2018). Finally, we recruited a relatively restricted sample of users to participate in our survey. As people with certain experiences of using smoking cessation $\mathrm{OHCs}$, the respondents from these two smoking-cessation $\mathrm{OHCs}$ suited our focus well. However, data could be collected from more countries to address the generalizability of our findings. Furthermore, our approach and findings point to the potential benefits of carrying out similar work with data from $\mathrm{OHC}$ s that are focused on other specific health concerns, such as problematic gambling or abuse of alcohol or other drugs.

\section{References}

Agarwal, R. (2000), "Individual acceptance of information technologies”, in Zmud, R.W. (Ed.), Framing the Domains of it Management: Projecting the Future through the Past, Pinnaflex Educational Resources, Cincinnati, pp. 85-104.

Agarwal, R. and Karahanna, E. (2000), "Time flies when you're having fun: cognitive absorption and beliefs about information technology usage", MIS Quarterly, Vol. 24 No. 4, pp. 665-694.

Albrecht, T.L. and Adelman, M.B. (1987), "Communicating social support: a theoretical perspective”, in Albrecht, T.L. and Adelman, M.B. (Eds), Communicating Social Support, Sage Publications, Newbury Park, CA, pp. 18-39.

Ali, R., Zhang, Z.Q. and Soomro, M.B. (2019), "Smoking-cessation acceptance via mobile health and quick response code technologies: empirical evidence of a pilot study from China and Pakistan", Current Psychology, Vol. 11, pp. 1-13.

Alraimi, K.M., Zo, H.J. and Ciganek, A.P. (2015), "Understanding the MOOCs continuance: the role of openness and reputation", Computers and Education, Vol. 80, pp. 28-38.

Bhattacherjee, A. (2001), "Understanding information systems continuance: an expectationconfirmation model”, MIS Quarterly, Vol. 25 No. 3, pp. 351-370.

Burns, R.J., Rothman, A.J., Fu, S.S., Lindgren, B. and Joseph, A.M. (2014), "The relation between social support and smoking cessation: revisiting an established measure to improve prediction", Annals of Behavioral Medicine, Vol. 47 No. 3, pp. 369-375.

Caraballo, R.S., Kruger, J., Asman, K., Pederson, L., Widome, R., Kiefe, C.I., Hitsman, B. and Jacobs, D.R. Jr (2014), "Relapse among cigarette smokers: the CARDIA longitudinal study-1985-2011", Addictive Behaviors, Vol. 39 No. 1, pp. 101-106.
Perceived usefulness of smoking cessation $\mathrm{OHC}$ 
INTR 32,7

Cavallo, D.N., Brown, J.D., Tate, D.F., DeVellis, R.F., Zimmer, C. and Ammerman, A.S. (2014), “The role of companionship, esteem, and informational support in explaining physical activity among young women in an online social network intervention”, Journal of Behavioral Medicine, Vol. 37 No. 5, pp. 955-966.

Chen, L.T., Baird, A. and Straub, D. (2019), "Fostering participant health knowledge and attitudes: an econometric study of a chronic disease-focused online health community", Journal of Management Information Systems, Vol. 36 No. 1, pp. 194-229.

Cheung, Y.T., Chan, C.H., Lai, C.K., Chan, W.F., Wang, M.P., Li, H.C., Chan, S.S. and Lam, T.H. (2015), "Using WhatsApp and Facebook online social groups for smoking relapse prevention for recent quitters: a pilot pragmatic cluster randomized controlled trial”, Journal of Medical Internet Research, Vol. 17 No. 10, pp. 1-15.

Cheung, Y.T.D., Chan, C.H.H., Wang, M.P., Li, H.C.W. and Lam, T.H. (2017), "Online social support for the prevention of smoking relapse: a content analysis of the WhatsApp and Facebook social groups”, Telemedicine Journal and E-Health, Vol. 23 No. 6, pp. 507-516.

Cheung, Y.T.D., Chan, C.H.H., Ho, K.S., Fok, W.P., Conway, M., Wong, C.K.H., Li, W.H.C., Wang, M.P. and Lam, T.H. (2020), "Effectiveness of WhatsApp online group discussion for smoking relapse prevention: protocol for a pragmatic randomized controlled trial”, Addiction, Vol. 115 No. 9, pp. 1777-1785.

Chin, W. (1998), “The partial least squares approach for structural equation modeling”, in George, A. (Ed.), Modern Methods for Business Research, Lawrence Erlbaum Associates, New York, pp. 295-336.

Chiu, C.M., Hsu, M.H. and Wang, E.T.G. (2006), "Understanding knowledge sharing in virtual communities: an integration of social capital and social cognitive theories”, Decision Support Systems, Vol. 42 No. 3, pp. 1872-1888.

Chuang, K.Y. and Yang, C.C. (2012), "Interaction patterns of nurturant support exchanged in online health social networking”, Journal of Medical Internet Research, Vol. 14 No. 3, pp. 1-21.

Cobb, S. (1976), "Social support as a moderator of life stress", Psychosomatic Medicine, Vol. 38 No. 5 , pp. 300-314.

Cohen, S. (2004), "Social relationships and health", American Psychologist, Vol. 59 No. 8, pp. 676-684.

Cohen, S. and Lichtenstein, E. (1990), "Partner behaviors that support quitting smoking”, Journal of Consulting and Clinical Psychology, Vol. 58 No. 3, pp. 304-309.

Cohen, S. and Wills, T.A. (1985), "Stress, social support, and the buffering hypothesis", Psychological Bulletin, Vol. 98 No. 2, pp. 310-357.

Coursaris, C.K. and Liu, M. (2009), "An analysis of social support exchanges in online HIV/AIDS selfhelp groups”, Computers in Human Behavior, Vol. 25 No. 4, pp. 911-918.

Cutrona, C.E. and Suhr, J.A. (1992), "Controllability of stressful events and satisfaction with spouse support behaviors”, Communication Research, Vol. 19 No. 2, pp. 154-174.

Davis, F.D. (1989), "Perceived usefulness, perceived ease of use, and user acceptance of information technology”, MIS Quarterly, Vol. 13 No. 3, pp. 319-340.

Deng, Z. and Liu, S. (2017), "Understanding consumer health information-seeking behavior from the perspective of the risk perception attitude framework and social support in mobile social media websites”, International Journal of Medical Informatics, Vol. 105, pp. 98-109.

Derks, D., Agneta, H.F. and Bos, A.E.R. (2008), "The role of emotion in computer-mediated communication: a review”, Computers in Human Behavior, Vol. 24 No. 3, pp. 766-785.

Dickerson, F., Savage, C.L., Schweinfurth, L.A., Goldberg, R.W., Bennett, M., Dixon, L., Daumit, G., Chinman, M. and Lucksted, A. (2016), "The experience of peer mentors in an intervention to promote smoking cessation in persons with psychiatric illness", Community Mental Health Journal, Vol. 52 No. 4, pp. 416-423. 
Flickinger, T.E., DeBolt, C., Waldman, A.L., Reynolds, G., Cohn, W.F., Beach, M.C., Ingersoll, K. and Dillingham, R. (2017), "Social support in a virtual community: analysis of a clinic-affiliated online support group for persons living with HIV/AIDS", AIDS and Behavior, Vol. 21 No. 11, pp. 3087-3099.

Fornell, C. and Larcker, D.F. (1981), "Structural equation models with unobservable variables and measurement error-algebra and statistics", Journal of Marketing Research, Vol. 18 No. 3, pp. 382-388.

Geisser, S. (1974), "A predictive approach to the random effect model”, Biometrika, Vol. 61 No. 1, pp. 101-107.

Graham, A.L. and Amato, M.S. (2019), "Twelve million smokers look online for smoking cessation help annually: health information national trends survey data, 2005-2017", Nicotine and Tobacco Research, Vol. 21 No. 2, pp. 249-252.

Graham, A.L., Papandonatos, G.D., Erar, B. and Stanton, C.A. (2015), "Use of an online smoking cessation community promotes abstinence: results of propensity score weighting", Health Psychology, Vol. 34, pp. 1286-1295.

Graham, A.L., Carpenter, K.M., Cha, S., Cole, S., Jacobs, M.A., Raskob, M. and Cole-Lewis, H. (2016), "Systematic review and meta-analysis of internet interventions for smoking cessation among adults", Substance Abuse and Rehabilitation, Vol. 7, pp. 55-69.

Granado-Font, E., Ferre-Grau, C., Rey-Renones, C., Pons-Vigues, M., Pujol Ribera, E., Berenguera, A., Barrera-Uriarte, M.L., Basora, J., Valverde-Trillo, A., Duch, J. and Flores-Mateo, G. (2018), "Coping strategies and social support in a mobile phone chat app designed to support smoking cessation: qualitative analysis", JMIR mHealth and uHealth, Vol. 6 No. 12, pp. 1-12.

Guo, Y. and Goh, D.H.-L. (2014), "I have AIDS': content analysis of postings in HIV/AIDS support group on a Chinese microblog", Computers in Human Behavior, Vol. 34, pp. 219-226.

Guo, J.L., Hsu, H.P., Lin, M.H., Lin, C.Y. and Huang, C.M. (2020), "Testing the usability of digital educational games for encouraging smoking cessation", International Journal of Environmental Research and Public Health, Vol. 17 No. 8, pp. 1-14.

Hair, J.F. Jr, Hult, G.T.M., Ringle, C. and Sarstedt, M. (2017), A Primer on Partial Least Squares Structural Equation Modeling (PLS-SEM), 2nd ed., Sage, Thousand Oaks.

Hamid, A.A., Razak, F.Z.A., Bakar, A.A. and Abdullah, W.S.W. (2016), "The effects of perceived usefulness and perceived ease of use on continuance intention to use e-government", Procedia Economics and Finance, Vol. 35, pp. 644-649.

Hashim, K.F. and Tan, F.B. (2018), "Examining the determinant factors of perceived online community usefulness using the expectancy value model”, Journal of Systems and Information Technology, Vol. 20 No. 2, pp. 152-167.

Henseler, J., Hubona, G. and Ray, P.A. (2016a), "Using PLS path modeling in new technology research: updated guidelines", Industrial Management and Data Systems, Vol. 116 No. 1, pp. 2-20.

Henseler, J., Ringle, C.M. and Sarstedt, M. (2016b), "Testing measurement invariance of composites using partial least squares”, International Marketing Review, Vol. 33 No. 3, pp. 405-431.

Hsu, M.H., Ju, T.L., Yen, C.H. and Chang, C.M. (2007), "Knowledge sharing behavior in virtual communities: the relationship between trust, self-efficacy, and outcome expectations", International Journal of Human-Computer Studies, Vol. 65 No. 2, pp. 153-169.

Hu, L.T. and Bentler, P.M. (1999), "Cutoff criteria for fit indexes in covariance structure analysis: conventional criteria versus new alternatives", Structural Equation Modeling: A Multidisciplinary Journal, Vol. 6 No. 1, pp. 1-55.

Huang, K., Chengalur-Smith, I. and Ran, W. (2014), "Not just for support: companionship activities in healthcare virtual support communities", Communications of the Association for Information Systems, Vol. 34 No. 29, pp. 561-594.

\section{Perceived usefulness of smoking cessation $\mathrm{OHC}$}


INTR 32,7

Huang, K.Y., Chengalur-Smith, I. and Pinsonneault, A. (2019), "Sharing is caring: social support provision and companionship activities in healthcare virtual support communities", MIS Quarterly, Vol. 43 No. 2, pp. 395-423.

Hulland, J. (1999), "Use of partial least squares (PLS) in strategic management research: a review of four recent studies", Strategic Management Journal, Vol. 20 No. 2, pp. 195-204.

Joseph, D.L., Chan, M.Y., Heintzelman, S.J., Tay, L., Diener, E. and Scotney, V.S. (2020), "The manipulation of affect: a meta-analysis of affect induction procedures", Psychological Bulletin, Vol. 146 No. 4, pp. 355-375.

Kock, N. and Lynn, G.S. (2012), "Lateral collinearity and misleading results in variance-based sem: an illustration and recommendations", Journal of the Association for Information Systems, Vol. 13 No. 7, pp. 546-580.

Li, H.X. and Liu, Y. (2014), "Understanding post-adoption behaviors of e-service users in the context of online travel services", Information and Management, Vol. 51 No. 8, pp. 1043-1052.

Liang, T.P., Ho, Y.T., Li, Y.W. and Turban, E. (2011), "What drives social commerce: the role of social support and relationship quality", International Journal of Electronic Commerce, Vol. 16 No. 2, pp. 69-90.

Matud, M.P. (2004), "Gender differences in stress and coping styles", Personality and Individual Differences, Vol. 37 No. 7, pp. 1401-1415.

Mohd Roffeei, S.H., Abdullah, N. and Basar, S.K. (2015), "Seeking social support on Facebook for children with autism spectrum disorders (ASDs)", International Journal of Medical Informatics, Vol. 84 No. 5, pp. 375-385.

Mpinganjira, M. (2018), "Precursors of trust in virtual health communities: a hierarchical investigation”, Information and Management, Vol. 55 No. 6, pp. 686-694.

Oatley, K. (1999), "Why fiction may be twice as true as fact: fiction as cognitive and emotional simulation", Review of General Psychology, Vol. 3 No. 2, pp. 101-117.

Oh, H.J., Lauckner, C., Boehmer, J., Fewins-Bliss, R. and Li, K. (2013), "Facebooking for health: an examination into the solicitation and effects of health-related social support on social networking sites", Computers in Human Behavior, Vol. 29 No. 5, pp. 2072-2080.

Peirce, R.S., Frone, M.R., Russell, M., Cooper, M.L. and Mudar, P. (2000), "A longitudinal model of social contact, social support, depression, and alcohol use”, Health Psychology, Vol. 19 No. 1, pp. 28-38.

Ploderer, B., Smith, W., Howard, S., Pearce, J. and Borland, R. (2013), "Patterns of support in an online community for smoking cessation”, in Prinz, W., Satchell, C., Koch, M. and Schlichter, J. (Eds), Proceedings of the 6th International Conference on Communities and Technologies, Munich, Germany, Association for Computing Machinery (ACM), New York, pp. 26-35.

Podsakoff, P.M., MacKenzie, S.B., Lee, J.Y. and Podsakoff, N.P. (2003), "Common method biases in behavioral research: a critical review of the literature and recommended remedies", Journal of Applied Psychology, Vol. 88 No. 5, pp. 879-903.

Prochaska, J.O. and Velicer, W.F. (1997), "The transtheoretical model of health behavior change", American Journal of Health Promotion, Vol. 12 No. 1, pp. 38-48.

Reifegerste, D., Wasgien, K. and Hagen, L.M. (2017), "Online social support for obese adults: exploring the role of forum activity", International Journal of Medical Informatics, Vol. 101, pp. 1-8.

Rocheleau, M., Sadasivam, R.S., Baquis, K., Stahl, H., Kinney, R.L., Pagoto, S.L. and Houston, T.K. (2015), "An observational study of social and emotional support in smoking cessation Twitter accounts: content analysis of tweets", Journal of Medical Internet Research, Vol. 17 No. 1, pp. 1-9.

Rook, K.S. (1987), "Social support versus companionship: effects on life stress, loneliness, and evaluations by others", Journal of Personality and Social Psychology, Vol. 52 No. 6, pp. 1132-1147. 
Saul, J.E., Amato, M.S., Cha, S. and Graham, A.L. (2016), "Engagement and attrition in Internet smoking cessation interventions: insights from a cross-sectional survey of 'one-hit-wonders", Internet Interventions, Vol. 5, pp. 23-29.

Song, X.L., Liu, Y.H., Jin, J.H. and Zhao, J.G. (2018), "Factors driving continued use of online health promotion competitions: evidence from an online weight-loss community", Online Information Review, Vol. 42 No. 6, pp. 802-820.

Stone, M. (1974), "Cross-validatory choice and assessment of statistical predictions", Journal of the Royal Statistical Society: Series B (Methodological), Vol. 36 No. 2, pp. 111-133.

Tamres, L.K., Janicki, D. and Helgeson, V.S. (2002), "Sex differences in coping behavior: a metaanalytic review and an examination of relative coping", Personality and Social Psychology Review, Vol. 6 No. 1, pp. 2-30.

Tenenhaus, M., Vinzi, V.E., Chatelin, Y.-M. and Lauro, C. (2005), "PLS path modeling", Computational Statistics and Data Analysis, Vol. 48 No. 1, pp. 159-205.

Thoits, P.A. (1986), "Social support as coping assistance", Journal of Consulting and Clinical Psychology, Vol. 54 No. 4, pp. 416-423.

Velicer, W.F., Prochaska, J.O. and Redding, C.A. (2006), "Tailored communications for smoking cessation: past successes and future directions”, Drug and Alcohol Review, Vol. 25 No. 1, pp. $49-57$.

Venkatesh, V. and Davis, F.D. (2000), "A theoretical extension of the technology acceptance model: four longitudinal field studies", Management Science, Vol. 46 No. 2, pp. 186-204.

Verheyen, C. and Goritz, A.S. (2009), "Plain texts as an online mood-induction procedure", Social Psychology, Vol. 40 No. 1, pp. 6-15.

Wagner, J., Burg, M. and Sirois, B. (2004), "Social support and the transtheoretical model: relationship of social support to smoking cessation stage, decisional balance, process use, and temptation", Addictive Behaviors, Vol. 29 No. 5, pp. 1039-1043.

Wang, J.C. and Chiang, M.J. (2009), "Social interaction and continuance intention in online auctions: a social capital perspective", Decision Support Systems, Vol. 47 No. 4, pp. 466-476.

Wang, P. and Li, H.X. (2019), "Understanding the antecedents and consequences of the perceived usefulness of travel review websites", International Journal of Contemporary Hospitality Management, Vol. 31 No. 3, pp. 1086-1103.

Wang, X., Zhao, K. and Street, N. (2017), "Analyzing and predicting user participations in online health communities: a social support perspective", Journal of Medical Internet Research, Vol. 19 No. 4, pp. 1-15.

Westermann, R., Spies, K., Stahl, G. and Hesse, F.W. (1996), "Relative effectiveness and validity of mood induction procedures: a meta-analysis", European Journal of Social Psychology, Vol. 26 No. 4, pp. 557-580.

Westmaas, J.L., Bontemps-Jones, J. and Bauer, J.E. (2010), "Social support in smoking cessation: reconciling theory and evidence", Nicotine and Tobacco Research, Vol. 12 No. 7, pp. 695-707.

White, J.S., Toussaert, S., Thrul, J., Bontemps-Jones, J., Abroms, L. and Westmaas, J.L. (2020), "Peer mentoring and automated text messages for smoking cessation: a randomized pilot trial", Nicotine and Tobacco Research, Vol. 22 No. 3, pp. 371-380.

World Health Organization (2014), "A guide for tobacco users to quit", available at: http://www.who. int/tobacco/publications/smoking_cessation/9789241506939/en/ (accessed 16 January 2020).

Wu, B. (2018), "Patient continued use of online health care communities: web mining of patient-doctor communication", Journal of Medical Internet Research, Vol. 20 No. 4, pp. 1-15.

Yan, L. and Tan, Y. (2014), "Feeling blue? Go online: an empirical study of social support among patients", Information Systems Research, Vol. 25 No. 4, pp. 690-709.
Perceived usefulness of smoking cessation $\mathrm{OHC}$ 
INTR 32,7

\section{4}

Yan, Z.J., Wang, T.M., Chen, Y. and Zhang, H. (2016), "Knowledge sharing in online health communities: a social exchange theory perspective", Information and Management, Vol. 53 No. 5, pp. 643-653.

Yuan, D., Lin, Z. and Zhuo, R. (2016), "What drives consumer knowledge sharing in online travel communities?: personal attributes or e-service factors?”, Computers in Human Behavior, Vol. 63, pp. 68-74.

Zhang, M. and Yang, C.C. (2015), "Using content and network analysis to understand the social support exchange patterns and user behaviors of an online smoking cessation intervention program", Journal of the Association for Information Science and Technology, Vol. 66 No. 3, pp. 564-575.

Zhang, P.Z., Li, T., Ge, R.Y. and Yen, D.C. (2012), "A theoretical acceptance model for computer-based communication media: nine field studies", Computers in Human Behavior, Vol. 28 No. 5, pp. 1805-1815.

Zhang, X., Liu, S., Deng, Z.H. and Chen, X. (2017), "Knowledge sharing motivations in online health communities: a comparative study of health professionals and normal users", Computers in Human Behavior, Vol. 75, pp. 797-810.

Zhang, X., Guo, F., Xu, T. and Li, Y. (2020), "What motivates physicians to share free health information on online health platforms?", Information Processing and Management, Vol. 57 No. 2, p. 102166.

Zou, H.M., Fang, Y., Sun, H. and Lim, K.H. (2018), "From usage to contribution: a synthesized typology of technology extra-role behavior", in 39th International Conference on Information Systems (ICIS 2018), San Francisco, CA, USA, Association for Information Systems, pp. 1-16.

Zupan, B. and Babbage, D.R. (2017), "Film clips and narrative text as subjective emotion elicitation techniques", Journal of Social Psychology, Vol. 157 No. 2, pp. 194-210. 
Appendix

Construct
(CI)

Perceived emotional support (PEMS)

Perceived esteem support (PESS)

Perceived informational support (PIS)

Knowledge sharing (KS)

\section{Measurement items}

(1) I intend to continue using the smoking cessation $\mathrm{OHC}$ rather than discontinuing my use of it

(2) I intend to continue using the smoking cessation $\mathrm{OHC}$ rather than use alternative online communities

(3) If I can, I will continue using the smoking cessation $\mathrm{OHC}$

(1) When I faced difficulties, some people in the smoking cessation $\mathrm{OHC}$ were on my side

(2) When I faced difficulties, some people in the smoking cessation $\mathrm{OHC}$ comforted and encouraged me

(3) When I faced difficulties, some people in the smoking cessation $\mathrm{OHC}$ listened to me talk about my personal feelings

(4) When I faced difficulties, some people in the smoking cessation $\mathrm{OHC}$ expressed interest in and concern for my well-being

(1) Some members of the smoking cessation $\mathrm{OHC}$ have shown confidence in my ability to deal with smoking

(2) Some members of the smoking cessation $\mathrm{OHC}$ have made me feel that I was good at making decisions about quitting smoking

(3) Some members of the smoking cessation $\mathrm{OHC}$ have made me feel that I was capable of handling my smoking cessation

(1) Some people in the smoking cessation $\mathrm{OHC}$ have been ready to offer suggestions when I needed help

(2) When I encountered a problem, some people in the smoking cessation $\mathrm{OHC}$ gave me information to help me overcome the problem

(3) When I faced difficulties, some people in the smoking cessation $\mathrm{OHC}$ helped me discover the cause and offered suggestions

(1) I participate frequently in knowledge-sharing activities in the smoking cessation $\mathrm{OHC}$

(2) I usually devote lots of time to knowledge-sharing activities in the smoking cessation $\mathrm{OHC}$

(3) I usually share information actively with others in the smoking cessation $\mathrm{OHC}$

(4) I usually get involved in discussion of various topics in the smoking cessation $\mathrm{OHC}$

\section{References}

Bhattacherjee

(2001)

Liang et al. (2011)

Oh et al. (2013)

Liang et al. (2011)

Hsu et al. (2007)

\section{usefulness of smoking cessation $\mathrm{OHC}$}

Perceived cess 
INTR

32,7

\begin{tabular}{lll}
\hline Construct & Measurement items & References \\
\hline $\begin{array}{lll}\text { Perceived usefulness } & \text { (1) } & \text { Using the smoking cessation OHC made my smoking } \\
\text { (PU) } & \text { cessation proceed more quickly (improving efficiency) } & \begin{array}{l}\text { Bhattacherjee } \\
\text { (2001) }\end{array} \\
& \text { (2) } \begin{array}{l}\text { Using the smoking cessation OHC made my smoking } \\
\text { cessation proceed better (improving performance) }\end{array} & \\
& \text { (3) } \begin{array}{l}\text { Using the smoking cessation OHC helped me make } \\
\text { better decisions about my smoking cessation }\end{array} & \\
& \text { (effectiveness) } & \\
& \text { (4) } \begin{array}{l}\text { Overall, using the smoking cessation OHC was useful for } \\
\text { smoking cessation }\end{array} & \\
\end{array}$
\end{tabular}

\section{Corresponding author}

Chenglong Li can be contacted at: chenglong.li@utu.fi

For instructions on how to order reprints of this article, please visit our website: www.emeraldgrouppublishing.com/licensing/reprints.htm Or contact us for further details: permissions@emeraldinsight.com 